\title{
Introduction: Indigenous Peoples, Extractivism, and Turbulences in South America
}

\section{Juan Javier Rivera Andia and Cecilie Vindal Ødegaard}

The edited volume we present here examines indigenous life-making projects in the encounter with extractivist politics and operations. It includes ethnographic studies of Amerindian strategies performed to face the 'slow violence' (Nixon 2013) or the turbulences (Bessire 2014) undergone by human-nonhuman relationships in contexts and sites of extractivism in South America. We explore how alternative politics of nature are negotiated and mediated in arenas where the extractive industries increasingly privatise and commodify 'the common good' (Blaser and de la Cadena 2017). With attention to the continuous and asymmetrical confrontations and entanglements of different politics of nature, we examine the various ways in which extractivism actualises questions of ontological difference. We explore how indigeneity is represented, performed, and recreated-by

\footnotetext{
J. J. Rivera Andía $(\bowtie)$

Universitat Autònoma de Barcelona, Barcelona, Spain

C. Vindal Ødegaard

University of Bergen, Bergen, Norway

e-mail: cecilie.odegaard@uib.no

(C) The Author(s) 2019

C. Vindal Ødegaard, J. J. Rivera Andía (eds.), Indigenous Life

Projects and Extractivism, Approaches to Social Inequality and

Difference, https://doi.org/10.1007/978-3-319-93435-8_1
} 
indigenous as well as national and international actors-in struggles over extractivist politics and endeavours. As we address these issues, we highlight our contributors' detailed ethnographic approaches. Indeed, the chapters we have assembled are grounded in the long-standing fieldwork experiences of their respective authors. We look beyond the boundaries of popular and academically fixed regions, as, for instance, the Andes and Amazonia, by including chapters from various countries and geographical regions of South America whose differences are usually taken for granted rather than explored and debated. Although study of resource extractivism in the region is growing, it tends to focus on wider national and international politics, often at the cost of the micropolitics and perspectives of indigenous groups. In this introduction to the volume, we provide a framework for the main preoccupations and perspectives addressed in the different chapters and their ethnographic insights and arguments.

\section{South American Turbulences}

Rights of the earth (in Bolivia) or rights of nature (in Ecuador) have become part of national agendas and policies in South America, a region that includes many of the world's few remaining wilderness areas. Are we witnessing 'a movement for the right to exist differently' (Escobar 2016: 26)? Instead of allowing these movements to be swallowed by modern politics (de la Cadena 2014), indigenous life-making projects 1 - in a context considered both as potentially a 'massive producer of sustainable power' (Howe 2015: 232) and as threatening for environmental activists-are invoking nonhuman beings linked to the landscape (mountains, water, and soil) as actors in the political arena. In the Andes, for instance, the 'runakuna [indigenous people of Cuzco] engage in political practices that...the state cannot recognize...because...it would require its transformation, even its undoing' (de la Cadena 2015: 14). These invocations, which place local populations in opposition to states and multinationals, reveal divergences of basic ontological dynamics concerning what the world is made of, what is valuable within or about it, and why.

This search for possibilities to think otherwise has become particularly salient in a situation of ecologic crisis and the discourse on the Anthropocene. Considered the consequences of a particular practice of worlding, in which the status of the planet becomes an object of human design, the notion of Anthropocene-the term most commonly used to 'remark that humans are now the dominant environmental force on the Earth' (Caro et al. 2012: 185) —'scale up our imagination of the human' 
(Chakrabarty 2009: 206). Some authors consider also that this term, although problematic and contested (Haraway et al. 2016), has made the general public more receptive to alternative life projects and the possibility of conscious redesign of the planet (Blaser et al. 2004; Carstensen 2014; Shellenberger and Nordhaus 2011; Kawa 2016). For many, the formulation of indigenous alternatives to extractivist capitalism appears acute and has gained renewed attention in scholarly debates.

I am convinced that in the somber decades to come, the end of the world "as we know it" is a distinct possibility. And when this time comes... we will have a lot to learn from people whose world has already ended a long time ago — think of... the Amerindians who, nonetheless, have managed to abide, and learned to live in a world which is no longer their world "as they knew it". We soon will be all Amerindians. Anthropology would be thus in a position to furnish the new metaphysics of the "Anthropocene" (Viveiros de Castro 2015b: 16).

The inclusion of nonhuman entities in several contexts of South American political life appears to get new impulse with what we often refer to in anthropology as the turn to ontology. While ontology includes a variety of different perspectives beyond the scope of this introduction, we address only one of its central features: the attempt to rethink the relationship between humans and the material world in an effort to throw new light on modernist assumptions underlying Euro-American thinking, as well as anthropological theory and methodologies (Holbraad and Pedersen 2017). A central theme for several contributors to this attempt (some of whom work in South American Amerindian regions) (Viveiros de Castro 1992; de la Cadena 2010) is the problematisation of 'modern', Western dualisms between matter and thought, nature and culture, signifier and signified, and object and subject-an ontology of dualisms which are considered inherent to capitalism (e.g., Tsing 2015). According to Holbraad (2012), for instance, these dualisms are problematic not only because they 'are not shared worldwide' but also because they are implied in our own analytical models and ways of representing the other. Holbraad seeks to go beyond the trope of representation by suggesting the 'use [of] ethnography to transform analysis' (2012: xviii). He proposes a shift in anthropological analysis from epistemic orientations to ontological transformations by drawing on the way in which Cuban (Ifá) divination practices seek to transform the world (rather than represent it) by interfering with the very meaning of truth 
(2012: xviii): 'Convention relies on the assumption that the realm of symbols and the realm of things for which they stand are opposedculture to nature, representation to world' (2012: 44). According to Holbraad, the nature-culture dichotomy-implied in the distinction between signified (matter) and signifier (thought)—serves to reinforce the presumption that both anthropologists and the people they study are in the business of representation and not invention (2012: 46). From this perspective, the approach anthropologists have conventionally taken in issues of reality and metaphor, signifier and signified raises fundamental questions about their approach to difference and the risk of reducing it to a question of (or response to) something else, such as inequality or socio-economic processes (see, e.g., Ødegaard 2016). The tendency in some branches of anthropology has, for instance, been to reduce certain ritual and magical practices or 'beliefs' (e.g., attacks by blood-consuming killers called kharisiris in the Andes) to a manifestation of local populations' experience of inequality or loss and fear connected to the intrusive strangers of modernity (cf.: Ansión 1987; Portocarrero 1991). While such attacks cannot be separated from the (post)colonial encounter, their understanding as mere representations of something else-and apparently more real-may limit further exploration of ontological dynamics and underpinnings (Ødegaard 2016: 66; see also Penfield and Stensrud, this volume). '[S] uspended between the radical contingencies of fieldwork and the radical reflexivity of the anthropologist' (Pedersen in Boellstorff 2016: 400), we may thus be inclined to undermine ethnographic specificities and overlook ways of being or forms of life that depart from hegemonic Euro-American conventions (and which otherwise might have informed our development of analytical alternatives).

Other main exponents of the so-called ontological turn have argued for the importance of taking the radical alterity of conceptual universes seriously, giving focus to differences between worlds or ways of being rather than epistemological worldviews and ways of knowing (Viveiros de Castro 2004b; de la Cadena 2010; Hage 2012). Suggesting the term multinaturalism, Viveiros de Castro (1992, 1999, 2015a) problematises the dichotomy, present in standard Euro-American discourses on multiculturalism, between nature (as given) and culture (as variable), because such notions reduce difference to a matter of social projections. He has also criticised anthropologists' concern with animism, in South America and elsewhere, as mainly a question of epistemology (see Bird-David 1999), arguing that 
such practices should not be understood only in terms of knowledge or representation of reality (although other anthropologists have replied 'that epistemology need not be derealization' [Boellstorff 2016: 397]). Viveiros de Castro (1999) has thus problematised the ways in which anthropologists often attempt to explain what he considers non-Western ontologies by deriving them from (or reducing them to) epistemology. Instead of 'this massive conversion of ontological questions to epistemological ones', which Viveiros de Castro terms the hallmark of modernist philosophy, he defines animism ${ }^{2}$ as an ontology 'concerned with being and not with how we come to know it' (1999: 79). Hence, animism, he postulates, is the social character of relations between humans and nonhumans where both are immersed in the same sociocosmic medium (1998: 473). By suggesting this approach, Viveiros de Castro seeks to avoid an understanding of animism in an Amazonian context as simply a projection of differences and qualities of the human world onto the nonhuman world (1998: 474). As noted by de la Cadena (2010), this aspect of Viveiros de Castro's argument is relevant in the Andean context where human relations with mountains and other earth-beings cannot necessarily be understood as a 'cultural interpretation' of 'nature' (de la Cadena 2010: 365; 2014). These practices and relationships constitute worlds that should not be reduced to a matter of social projections nor can they be conceptualised as a fixed set of features: "one is never animist "in general", only in terms of assemblages that generate metamorphic transformation in our capacity to affect and be affected' (Stengers 2012).

Many authors working on different ethnographic regions around the world have, if not necessarily or directly criticised the turn to ontology, at least pointed out that 'we don't know what [the ontological turn] means yet' (Kelly 2014: 264). Taking into account its current relevance in mainstream anthropology, ontology has also been viewed as a sort of buzzword (Pedersen 2014; Halbmayer 2012: 11). Popularised at least since the publication of Thinking through Things (Henare et al. 2007), the turn is seen today as not 'particularly new anymore, let alone [lasting] forever' (Pedersen 2014). The coincidence of the turn to ontology with the contemporary inclusion of nonhuman entities in political life in South America indicates the interconnectedness of sociopolitical processes and academic endeavour. We evoke the question of ontology, ${ }^{3}$ considering its implications and effects, in an attempt to fully appreciate indigenous terms and experiences. 


\section{On Turns and Doubts: Critique and Politics}

The turn to ontology in anthropology has also come under harsh criticism (e.g., Turner 2009; Ramos 2012; Vigh and Sausdal 2014; Bessire and Bond 2014b) and has created divisions through heated debates with sometimes dramatic opposition (see Reed 2016). Some argue that the 'radicalising unfamiliarity [or] alterity' (Alberti et al. 2011: 906) of the turn to ontology, which seems to require 'the radical incommensurability of modern and non-modern worlds' (Bessire and Bond 2014a: 442) as an analytical point of departure, might lend itself to potentially dangerous political constructions of otherness that could be used against marginalised groups (Vigh and Sausdal 2014; Rival 2012a, b: 138; Carstensen 2014: 26; Rivera Andía 2015; Todd 2016: 10; Cepek 2016; see also Krøijer, this volume). Some of the more moderate critics of various aspects and implications of the ontological turn focus on flaws regarding hybridisations, the possible internal differences within ontologies, as well as the significance of its classifications (Ingold 2000; Halbmayer 2012; Pazos 2006, 2007; Willerslev 2007; Kohn 2013; Scott 2013; Piette 2012; Descola 2014a, c: 298; Neurath 2015: 59-60). Others ask whether proponents of the turn to ontology are taking indigenous animism too literally or dealing with abstractions that hardly apply to ethnography. In fact, some critics have equated the turn to ontology with a kind of dogma, suggesting that its proponents both advocate a sort of faith and reduce social and cultural life and relations to nothing more than idealised types (Oyuela-Caycedo 2014; Scott 2013; Killick 2015; Franklin 2017; Willerslev 2013, Keane 2013; Fischer 2014; Ramos 2012; Course 2010). Lucas Bessire and David Bond (2014a: 444) suggest that the restriction of 'indigenous ontological legitimacy' to the terms of an 'orthodox dialectic of Otherness' might in fact erase those individuals who do not correspond to the particular mythology in which the dialectic is exclusively grounded.

Other authors raise doubts about the alleged indifference of the ontological turn's proponents to current indigenous political concerns and adversities (Ramos 2012: 483-484). Following previous critiques of the representation of Western modern thought as an integral, homogeneous system of abstract-type concepts (Turner 2009: 16), Bessire and Bond have questioned the conditions under which ontologies are 'made amenable to ethnographic analysis' (Bessire and Bond 2014a: 443; see also Heywood 2012: 146; Gordillo 2014: 185-190). In his review of Holbraad's study, Evan Killick points out that 
[T]he complex ideas, practices and social processes of everyday life are overlooked in the intellectual pursuit of radical alterity... . [This] proposed methodological emphasis on alterity ... [has] the danger both of overinterpreting, or perhaps over-intellectualising, alternative views and practices... . [The] philosophical ideas become an end in themselves, not linked to raising further ethnographic questions or elucidating other social and cultural phenomenon but rather held up as precious jewels to be admired in isolation (Killick 2014).

In a similar vein, Bessire denounces the turn to ontology as a 'mystifying ethnographic project' based on the 'active omission of the conditions and relationships' that allow anthropological knowledge (Bessire 2014: 39). At the same time, he advocates paying more attention to the influence of anthropological knowledge on Amerindian destinies and the unequal forces that such knowledge can exert against indigenous peoples (Bessire 2014: 26). Furthermore, this ethnographer notes that the emphasis on ontology 'standardizes multiplicity and fetishizes alterity' (Bessire and Bond 2014a: 449; see also Rivera Andía 2015; Wardle and Schaffner 2017: 21; Todd 2016: 17; Cepek 2016). A few years earlier, Ramos suggested that 'to attribute so much uniformity to native thinking... is to flatten down (if not deny) [native] inventiveness and aesthetic sophistication and to ignore... specific historical trajectories' (Ramos 2012: 483). Finally, Candea recognises that the question of interlocution has not been 'conclusively addressed' in the ontologically inflected anthropology: 'whom, precisely, is one "taking seriously," and what might a disagreement or response from them look like?' (Candea 2014). These authors remind us of the need to explore "both the possibility of an "other" politics and the possibility of there being other than politics' (ibid.) in the context of the urgent problems facing indigenous peoples (e.g., Bessire and Bond 2014c).

In answer to the criticisms, two of the main proponents of the ontological turn have both emphasised the political dimension of their theoretical proposals. Descola asserts that ontology enhances the anthropological study of politics when it comes to indigenous movements that see nonhumans as political subjects in their own collective (collectif) (Descola 2014b: 348):

[I]t is precisely our attempt to do away with those Eurocentric categories [class, race, gender] and with the colonial project of sucking into our own cosmology peoples who, having lost their lands, their dignity, and their work-force, face the added ignominy of having to translate their ways of life into our own way of life and of being grateful to us for providing them the tools to do so (Descola 2014d: 436). 
Also at stake is anthropology's relation to both the domain of politics per se and the spectrum of possible analyses of the enactment and constitution of politics (see Bertelsen and Bendixsen 2016: 4-5). According to Viveiros de Castro (2015b), ontological questions are political questions insofar as they come into existence only in the context of friction and divergence between concepts, practices, and experiences.

For authors like Gassan Hage (2012), the future of a critical anthropology is one that has the potential to encourage as well as generate different forms of politics, relying precisely on a recognition of ontologically differentiated alterity and difference. Similarly, according to de la Cadena (2014), an ontologically informed anthropology contains the possibility to unfold the situated conditions of modern politics and a potential to unsettle its hegemony. Politics in the modern era, de la Cadena argues, is based on a distinction between humanity and nature, where the representation of nature in political life requires science. For centuries, indigenous people have been excluded from modern politics, being considered too close to nature and incapable of modernity. In this view, the status of indigenous people is intimately connected to the notion of modern politics and the nature-culture dichotomy, which undergirds the long-standing exclusion of indigenous people from politics. With increasing protests against extractive industries in South America in recent years, where nonhuman beings are actualised in political life, there is an unsettling of these long-established oppositions related to the nature-culture dichotomy.

An issue that has caught the attention of social scientists relatively recently is the way in which the ideologies and worldings (sometimes called naturalism) that accompany the industrial extraction of what is commonly denominated natural resources coexist with an alternative politics of nature. Referring to the politicisation of landscape and recent years' actualisation of earth-beings in protests and political life (de la Cadena 2010), this notion pinpoints the inclusion of nonhuman entities in the sphere of politics. Central to this alternative politics of nature are indigenous ways of cohabiting with an active, and living landscape, which is considered not as an inert object for humans to own, dispose of, or exploit but filled with nonhuman persons with whom one can or even must relate. Several scholars have recently taken an interest in how the inclusion of nonhuman entities in political life may potentially disrupt (and multiply) the dichotomies on which the understanding of politics is built (i.e., nature-culture, object-subject, science-politics) (Stengers 2012; Course 2010; Latour 2005, 2014; Law and Lien 2012). Interestingly, such a 
capacity to redefine the sensible world as an instrument of struggle is growing in significance far beyond the local in a period of history when the neoliberal paradigm is gaining ground as a mode of governance accommodating for market liberalisation (along with the introduction of new labour laws that promote low-term outsourcing, the privatisation of national services, and the criminalisation of poverty) ( $\mathrm{Li} 2015: 73)$. What is the scope of this mobilisation around entities of the landscape? As is widely recognised, the inclusion of indigenous world- and life-making projects and of nonhuman entities in the sphere of politics provide an idiom for action, an imaginary for critique, and the formulation of political alternatives. It has also turned into a resource for both protest movements and constitutions in contemporary South America, as well as for the (again) Euro-American imagination-including academic and anthropological thinking. While, historically, South American nation-state leaders and authorities have predominantly defined the indigenous as an unproductive other, as incompatible with prevailing notions of modernity and progress, researchers and activists are currently revitalising the emergent life-making projects of indigenous people as a source of critique and in the formulation of utopian futures (Rivera Andía 2005a). In the following pages, we discuss the possibilities and issues related to these tendencies.

Central for many proponents of ontological approaches to anthropology-also as regards anthropology's political potential -is the attempt to reinvent it as a comparative discipline. Following this line of reasoning, one of anthropology's central aims should be to draw on different ways of being in the world in order to rethink Euro-American categories. Tim Ingold, however, has criticised what he considers the deep asymmetry of some of these comparative projects. At the end of the day, he argues, this mode of comparison still places the anthropologist in the role of emancipated observer, free to move around in the domain of human diversity:

[T] he observer has no place, he is nowhere, he does not recognise any ontology as his own... [H] affirms that he is an ontological pluralist. One might say that he observes the world from a sort of ontological paradise from which we are all excluded, we who are imprisoned by our respective philosophies of being... . [F]rom his position of transcendental observer, he could thus affirm that there are different manners of composing a unique world. But this transcendental posture is in fact one of the bases of what he calls naturalist ontology... . [W] hatever he might say, he adopts as a neutral position a certain ontology: naturalism (Ingold in Descola and Ingold 2014: 54). ${ }^{4}$ 
Along similar lines, other scholars, such as Severin Fowles, have argued
that

[O] ur modernist ontology is inseparable from what we might call the exceptional position of nonposition. Whatever the world is, there must always be some position of nonposition outside it for the Western liberal subject to occupy, as reason stands apart from emotion, mind from body, referee from players, scientist from experiments, anthropologist from natives. In this sense, there is nothing more profoundly modern than the effort to step outside modernity. And this is precisely what the advocates of the ontological turn claim to have accomplished twice over: first by standing in the position of nonposition vis-à-vis other people's worlds and second by standing in the position of nonposition vis$\grave{a}$-vis the plurality of worlds itself (Fowles in Alberti et al. 2011: 907).

So how do we 'account for ontological encounters when any account presupposes an ontological grounding?' (Blaser 2009: 18). Is an anthropologist actually a 'masked moderniser who, under cover of pluralism, in fact, restores anthropological science's guiding function and therefore reinforces the Western in its intellectual imperialism'5 (Descola 2014b: 116)? The answers to these critiques could be seen as entailing a sort of retreat from the idea of a 'big theory' (ibid.) or 'a metaphysical issue best left to philosophers' (Holbraad in Alberti et al. 2011: 908). As we return to below, some proponents of the ontological turn in anthropology have indeed reacted by putting their strongest efforts in a rethinking of anthropology's methodological and comparative devices.

The edited volume we present here seeks to cast light on these debates by providing ethnographic studies of those world- and life-making projects that are currently being formulated by South American indigenous actors in response to ongoing politics of extractivism. Several issues arise when identifying lessons which can be learnt from indigenous positions in the local extractivist contexts of global capitalism. For instance, is it possible to raise this question about 'lessons learnt' in the first place, without jeopardising indigenous peoples and reproducing a notion of the noble savage? Do we thus risk encapsulating people within a constricted terrain of the permitted Indian or into a fetishised radical difference in which some hierarchically ranked world-making projects count more than others? While raising these questions, we do not try to make a particular methodological statement in this introduction, inasmuch as we do not intend to sharply 
demarcate the position or theoretical lines of contrast among the arguments summarised above or to discuss in detail the adequacy of any of them. We aim, rather, to modestly situate some of the still-evolving issues at stake.

\section{To Think Otherwise in Amerindian Extractivist Contexts: Towards an Engaged Ontography}

Both critics and proponents of the use of the term ontology could probably agree that there is still much to be learnt about, first, how indigenous groups detect and use particular properties of their environments and, second, how they change this environment 'by weaving with it and between themselves' diverse kinds of relations (Descola 2014c: 273). Subsequently, studies that tend to restrict the ontological turn to a reasonable and productive methodology (for instance, Holbraad's 'ontography') seem less affected by the strong criticisms of the philosophical or metaphysical premises reviewed above (Holbraad 2009, 2014; see Wardle and Schaffner 2017: 17-21). Pedersen, for example, considers the ontological turn as 'a strictly methodological proposal':

[The ontological turn] is the methodological injunction to keep this horizon perpetually open, including the question of what an object of ethnographic investigation might be and, therefore, how existing genres, concepts and theories have to be modulated the better to articulate it... . [T] he ontological turn is not concerned with the "really real" nature of the world... [It] is a methodological project that poses ontological questions in order to solve epistemological problems... . [E]pistemology in anthropology has to be about ontology too (Pedersen 2017: 229-230).

Stressing the turn to ontology as a 'commitment to recalibrate the level at which analysis takes place' (Course 2010: 248), Holbraad has characterised the turn as a radicalisation of three basic anthropological requirements: reflexivity, conceptualisation, and experimentation (Holbraad in Alberti et al. 2011). He insists on the rejection of any previous compromise concerning the types of phenomena that could constitute the focus of an ethnographic discipline and how anthropological concepts could be transformed in order to observe them. His radicalisation of reflexivity indeed gives conceptualisation a central place in the ontological turn, which aims to transform critical reflexivity 
into what he considers conceptual creativity (Holbraad 2014: 128-137). Consequently, Holbraad describes his ontographic approach as a 'break out of the circle of our conceptual repertoire' (2009: 433) using 'the extraordinary data to reconceptualize ordinary assumptions in extraordinary ways' (Holbraad 2009: 435; see also Lebner 2017: 225; Wardle and Schaffner 2017: 11):

[T]he task of conceptualization that any given set of animist phenomena may necessitate may certainly involve engaging with Western ontological revisions, but is most likely to require analytical labour that goes further than that (Holbraad 2009: 436).

\section{Further:}

[T]he turn to ontology in anthropology is not about offering some suitably improved and ontically fortified replacement for culture. Rather, it is about offering a better way to address just one of the questions "culture" was always supposed to absorb-namely, the analytical problem of how to make sense of things that seem to lack one (Holbraad in Alberti et al. 2011: 902).

This is what ultimately lies behind statements such as this from Viveiros de Castro: 'Anthropology's role, then, is not that of explaining the world of the other, but rather of multiplying our world' (2015b). In fact, there are various concordances between Holbraad's concept and Viveiros de Castro's proposals. The latter has written about what he calls 'speculative ontography' (2015a: 75) and declared that the most interesting thing in perspectivism is not that it illustrates an ethnographic phenomenon, but that it illustrates a methodological imperative for anthropological thinking: the need to be able to exert radical reconceptualisations (ibid.). The reflexivity similarly implied in Holbraad's ontography echoes the 'reversibility' pursued by the 'new anthropological epistemology' proposed by Corsín Jiménez and Willerslev (2007). It also resonates with Strathern's well-known proposal: 'It matters what ideas we use to think other ideas.' Some of her colleagues have expanded and updated the proposal to: 'It matters what worlds world worlds' (Haraway 2016: 35).

Throughout this volume, we are interested in emphasising the importance of ethnographic field studies for further theoretical development. We acknowledge that detailed research is necessary to understand the multiplicity of conceptual and practical relationships that humans establish with their environment. 
[It] tends to be ethnography, the actual words, actions and ideas of other people that generate alternative versions that are much more complex and novel than anything "we" can dream up (Killick 2014).

We seek to facilitate, in the South American context, the use of anthropological imagination and the forging of new concepts and approaches that could re-establish ethnography as 'the prime heuristic in anthropology' and return it to the foreground of current conceptual developments (HAU n.d.). We want to test this ethnographic engagement using a detailed empirical basis for arguments about the role of extractivism in the discontinuities or reproductions of indigenous worlds that is not beholden to the most recent theoretical developments.

\section{Extractivism, Enclosure, and Protests}

During the last few decades, there has been an ongoing extractivist boom in, but not limited to, South America. Following World Bank and International Monetary Fund prescriptions that, during the 1990s, encouraged the relaxation of conditions for foreign investors in the mineral sector of developing countries (Ballard and Banks 2003: 294), investments in mining explorations increased dramatically: 90 per cent worldwide, 400 per cent in Latin America, and 2000 per cent in South America. In Peru, mining activity now affects more than half of the 6000 peasant communities (Li 2015: 16). Extractivism epitomises the contemporary situation in many South American countries in several ways, raising issues of environmental degradation, sustainable development, resource sovereignty, and vulnerable (often indigenous) populations' position and options. During the last couple of decades, governments across the political spectrum throughout the region have relied increasingly on the extraction of natural resources, representing extraction and export as key to economic growth and progress (Arsel et al. 2016), while often tolerating cyanide-leaching technologies and offering minimal environmental regulation, low labour costs, as well as low tributary payments ( $\mathrm{Li} 2015$ : 81).

The current stronghold of the extractive industries in South America has been driven by the high commodity prices of the early twenty-first century, the global demand for energy and minerals, as well as technological changes in the mining industry itself (Bridge 2004; Li 2015; ChiassonLeBel 2016). High commodity prices, or the so-called commodity boom, in particular, are often blamed for fostering what Svampa (2013: 31-36) has 
called the 'commodity consensus': a tacit agreement by most Latin American governments, both left and right wing, made in the absence of real alternatives to the exploitation of internationally traded commodities (see also Chiasson-LeBel 2016: 1). As noted by Hasland and Heidrich (2016), the commodity boom reshaped the model of development throughout South America and elsewhere in the Global South. In some countries, these national policies have been dominated by foreign capital, while in other countries (i.e., Venezuela, Brazil, Bolivia, Ecuador) developments have taken shape as governments have increased taxes and royalties on the resource sector, foreign firms have been nationalised, and public spending on social and developmental goals has increased (ibid.; see also Gudynas 2011, 2018). While there are, thus, certainly national specificities characterising the role of extractive industries in South American countries, as well as different political and economic policies, the extraction of oil, gas, metals, and minerals shows continuities across different types of regimes over time and across space in the region (Bebbington and Bebbington 2012; Li 2015).

The latest commodity boom coincided with the Pink Tide in South America-the elective victories of progressive forces that in many countries changed policies and attitudes towards the extractive sectors. As the prices of metals, oil, and gas roughly tripled, several countries in the region followed in the footsteps set by Venezuela in 1998 and Brazil in 2002, some electing radical and others more moderate leftist presidents driving the 'progressive neo-extractivism'. High commodity prices helped the new political leaders push their political agenda: break with the dominance of the neoliberal development model and give the state a central role in extractive sectors and in programmes to tackle poverty and development. However, this new shape of the 'extractive imperative' (Arsel et al. 2016) went against these presidents' initial promises to respect the rights of indigenous communities, social movements, and the environment. In effect, civic concerns and demands concerning the expansion of mining, oil, and gas extraction produced a proliferation of conflicts, especially at the local level. According to the United Nations Environment Programme (UNEP), at least 40 per cent of inner conflicts of the last 60 years have, in one way or another, been linked to natural resources. Between January 2011 and October 2015, however, commodity prices fell dramatically, ${ }^{6}$ and, for a period, the price of hydrocarbons even returned to pre-boom levels (Arsel et al. 2016). Several countries with large extractive sectors entered a period of economic and fiscal crisis, 
particularly Venezuela. Among the available policy responses, Arsel et al. (2016) note, has been to further increase extraction in areas that invariably intrude on landscapes and territories on which indigenous and other marginalised communities depend (ibid.: 877-878).

Following these developments, researchers in the social sciences have once again made the extractive industries a central theme, often with a focus on the interconnectedness between extractivism and politics (Mitchell 2011; McNeish et al. 2015), as well as the social and environmental effects of extractivism and protests made in response. In effect, the notion of extractivism has become widely used to pinpoint the extractive industries as a defining feature of political and economic life. As a descriptive term, extractivism may refer to modes of accumulation based primarily on the removal of large quantities of 'raw' materials (especially of minerals and oil but including also farming, forestry, and fishing) which are either not processed or are processed but only to a very limited degree and which are extracted, in particular, for international markets (ChiassonLeBel 2016: 2; see also Acosta 2011, 2013; Vetlmeyer and Petras 2014; Matthes and Crncic 2012). While the term may serve primarily descriptive purposes referring to the extraction of 'natural resources', it is used also as an analytical term referring to particular developments in domestic and global economies. Indeed, the term was first developed as a critique of the development model adopted by many countries in the Global South (Bunker 1984) and shares some common ground with, for instance, dependency approaches to development, problematising the reliance of certain national economies on the extraction of raw materials for exports (whether minerals, hydrocarbons, fishing, or agricultural products). Hence the term has gained ground in scholarly attempts to take issue with the importance of primary resources for export among national economies, especially in the Global South, simultaneously including a focus on environmental concerns (see Gudynas 2011: 25-27; Chiasson-LeBel 2016: 2). More recently, the concept neo-extractivist economy has frequently been applied in critiques of Latin American governments associated with the Pink Tide that continued to rely on an extractivist economy. Neoextractivism, then, expresses the unfulfilled expectations that left-wing governments would radically change the development model to move away from a commodity export-led model (Chiasson-LeBel 2016: 2). As Chiasson-LeBel notes, and as Horst discusses in the preface to this volume, the situation depicted through these terms is far from new-not even within the energy sector-considering that petroleum, for example, has 
been a dominant product for the Venezuelan economy since the 1920s and for Ecuador since the 1970s.

While the term extractivism was originally developed in reference to the heavy reliance of nation-states on the extraction of raw materials, a few scholars have recently tried to broaden the term to include different forms, practices, and dimensions of value extraction from all areas of life, including social ties and practices of social cooperation (Gago 2015). The extractivist economy in this sense epitomises particular dimensions and developments of contemporary global capitalism, especially those related to the commodification of new areas of life (i.e., in the form of big data, carbon markets, social cooperation, cultural identities, and imageries, etc.). We can view these various forms of commodification as both a continual expansion of sources for value accumulation and-the dominant form of accumulation by which elite power is restored-the dispossession of some parts of the population (Harvey 2007). Such a broad understanding of extractivism may draw attention to different dimensions of how capitalist projects extract value from a range of different forms and areas of life not previously part of capitalist commodification and accumulation, revealing how extractivist dynamics may embrace and affect all aspects of life (see, e.g., Krøijer, Brightman, Penfield, and Ødegaard, this volume). In the context of South America, these less conventional dynamics of extractivism are made particularly evident through green finance as well as carbon and biodiversity accounting in and through global carbon market programmes. Our concern with extractivism in this edited volume is not limited to the extraction of minerals, metals, or fossil fuels but includes issues of forests (Marc Brightman's chapter) or water (Astrid Bredholt Stensrud's chapter) and even issues related to the imminent but still spectral appearance of extractive projects (Juan Javier Rivera Andía's chapter). Therefore, we seek to engage the issue of extractivism and extractions of value in a broad sense. ${ }^{7}$

The extraction of primary materials in South America has affected, most visibly and dramatically, vulnerable populations, such as rural communities and indigenous groups. The resulting protests have often been motivated by concerns with environmental effects in local communities, a common disregard of laws about prior consultation, ${ }^{8}$ changes of landscape and land use, limited employment opportunities for local populations, ${ }^{9}$ and land grabs. Scholars have tried to pinpoint the challenges that the extractive industry may pose for local populations with the notion of enclosure, drawing on Marx by pointing to the enclosure of the commons 
and the separation of peasants from the land. According to Bridge, enclosure and exclusion are central to the creation of value in the extractive sector, in many cases instigated through the extension of state-granted concessions to private companies or to state-corporate consortiums (2008: $415)$. He argues that the often nonrenewable character of extraction may even imply that enclosure is a primary competitive logic in extractive industries, a prerequisite for which is the existence of vulnerable populations who have no legal, or otherwise ambiguous, ownership of land. Along similar lines, and seeking to understand the relations between enclosure, commodification, and struggle in the extractive industries, Bebbington and Bury (2014) discuss the accelerated rate of the extractive industry's recent expansion in South America, arguing that several countries in the region are currently undergoing a process of increasingly extensive enclosure. They note that enclosure is indeed central to the commodification of various parts of the landscape, and that it lays the basis for new rounds of landscape transformation as, for example, businesses seek to gain access to these commodities (2014: 11).

Landscape transformations as a result of the operations of extractive industries also create an important backdrop for the recent politicisation of nature. In recent years, mega-mining projects and the use of new technologies in the extractive industries have particularly broadened the extent of this landscape transformation (see Li 2015), sometimes resulting in the destruction of whole mountains, pasturelands, and water sources. As Li (2015) discusses in her study of mining in Peru, mining projects may transform people's relations of access to a wide range of resources. In the Andean context, recent forms of extractivism stand in contrast to previous, more low-tech and labour-intensive forms, and the practices by which locally based miners would give offerings (of food, alcohol, coca) to both appease the powerful earth-beings in exchange for the removal of mineral wealth and secure their own safety (see Li 2015; Harris 2000; Nash 1979). The recent mining landscape transformations exacerbate the disruption of forms of life and ways of living, and, as Li shows, have the potential to disturb relationships between people and an agentive and living landscape, sometimes through specific devices, such as buildings (see Juan Javier Rivera Andía, this volume). Li asks (2015: 75): 'How, then, does one argue with an evolutionist logic in which mining is portrayed as the inevitable road to progress?' Regarding the environmental conflicts of recent years, one of Li's central points concerns mountains. Mountains in such conflicts are not simply a landform or a resource nor a matter of differing 
perceptions among the actors involved in the controversy. Rather, protesters have mobilised elements that are usually absent from public debate: Apus, usually described as spirits of the mountains in the Andes. Through protests, apus have been brought into the sphere of national politics and become entities with which corporations and the state must contend (ibid.: 110-111; see also Harvey and Knox 2015). On the one hand, some scholars have criticised this approach for taking too seriously entities that are actually much less fixed and respected than created as a relatable fact in encounters with activism and protests (Cepek 2016; see also Krøijer, this volume). On the other hand, other authors have proposed that this inclusion of apus in politics can be considered the enactment of ontological politics of different worlds. For instance, and as previously noted, Blaser (2009) and de la Cadena (2010) have emphasised that contemporary environmental struggles in South America are also conflicts over different realities or worlds. According to the latter, this implies that:

no separation exists between Ausangate the Word and Ausangate the earthbeing; no "meaning" mediates between the name and the being. [Mountain] Ausangate is, period. Not a belief but a presence enacted through everyday practices (de la Cadena 2015: 25-26).

The conflicts do not simply concern competing interpretations of naturescholars such as de la Cadena and Blaser argue-but can be understood as the enactment, stabilisation, and protection of multiple socionatural worlds. ${ }^{10}$ As similarly noted by Li: 'Conflicts over mining reveal the multiple ways of configuring what we usually conceive of as "Nature" and its constituent elements' ( $\mathrm{Li} 2015$ : 22-23).

Considering the intensity of extractive operations in South America over the last two decades, several scholars from different disciplines have explored the significance of these developments, examining the many facets of struggle and protest surrounding extractivism in the twenty-first century (Bebbington and Bury 2014; Deonandan and Dougherty 2016; Arsel et al. 2016; Jalbert et al. 2017). Some studies focus on practices of resistance from a critical ethnographic perspective (e.g., Jalbert et al. 2017) and the implications of extractivism as a catalyst for conflicting conceptualisations of nature, region, and nation (Escobar 2016; Bebbington and Bury 2014), which are often specifically related to different kinds of reactions (usually but not always practices of resistance) to resource extraction. That which distinguishes these studies from the volume we present 
here is our intent to more explicitly relate the current projects and debates of extractivist expansion in South America to the issues of mobilisation, difference, and ontology in local indigenous settings. More specifically, we seek to explore the significance of ontological and cosmological questions to how local populations negotiate and navigate extractive operations and politics. The volume, therefore, addresses ongoing debates on the ontological turn in anthropology, exploring the different ways in which extractivism actualises questions of ontological difference. Our concern is how the intensification of extractivist endeavours in South America actualises issues of both indigeneity and ontology in specific ways and in concrete situations and contexts.

In this Amerindian scenario, politics can be considered to entail questions of fraught and perpetual worldings, which are different although thoroughly imbricated (Povinelli 2001). Politics becomes a cosmopolitics (Stengers 1996) that questions taking human rights as the ultimate justification for claims mobilised through identity politics (Haraway 2008). In this regard, and considering how modern politics is premised on scientific representations of nature, de la Cadena (2014) proposes we explore precisely that which historically falls outside politics-such as earth-beings in the Andes-in order to eliminate the blind spots of modern politics. Such ethnographies may enable us to conceptualise otherwise in partial connection (see Strathern 2004) with difference (which, being located at sites of limit, emerge as radical difference). Indeed, paying attention precisely to such ethnographic (and postcolonial) moments that oblige analysis at the crossroads of ontology and modern politics could open the latter to a more radical critical view (de la Cadena 2014; see also Salmond 2014: 178). Several contributors writing about the ontological turn have considered that, if we are to escape the catastrophic effects of further environmental degradation and climate change, we may need to consider the idea of a 'world not predicated on the essential difference of Indigenous peoples but on our shared capacity to transform ourselves' (Bessire 2014: 227; see also Alberti et al. 2011: 898; Killick 2015).

What happens when the practices and ideologies of extractivism play out in places where the components of the world are otherwise entangled? Further, what would happen if we try to temporarily abstain from seeing resistance and social conflicts as the conceptual points of departure but also as emerging facts from the field? We wish to open the debate also to other possible problems. Do extractivist and Amerindian ontologies differ radically? And, if so, in what ways do they interact or mutually entangle each 
other? Are they, rather, kept separate, and, if so, by what means and under what circumstances? What roles do inequality and asymmetry play in entanglements and separations? Perhaps more importantly, how can we ethically address the suffering, dispossession, destruction, and corruption (Ballard and Banks 2003; Gudynas 2018) that entanglements and asymmetries 'that [admit] no exception and [tolerate] no resistance' (Arsel et al. 2016) provoke in South America? ${ }^{11}$ And, finally, if we are to take these considerations into account, to what extent must we expand our own anthropological concepts in order to grasp 'how "other" the otherwise can be' (Candea 2014) or how 'ontologies multiply' (Law and Lien 2012: 15)?

\section{Identity Politics and Indigenous Mobilisation}

It was not until the 1980s and 1990s, as lowland groups started organising around indigenous identity and demands for territory and highland groups mobilised around cultural recognition and political participation (Postero 2013: 109), that indigeneity emerged as a way of claiming citizenship, rights, and justice. This emergence of indigenous mobilisations and organisations in South and Central America (see, for instance, Warren and Jackson 2002; Ramos 1998; Álvarez et al. 1998; Canessa 2006; Postero 2013) was sparked in part by an international discourse of indigenous rights as well as the more general turn towards identity politics worldwide.

Defining and representing indigeneity is a subject of great debate in South America, as it is elsewhere in the world. Considering the way in which indigenous peoples ${ }^{12}$ tend to be understood and defined in contrast to modernity and that which is associated with the market economy, the relationship between indigeneity and capitalism represents a central theme in anthropological writings. Some scholars have emphasised that capitalism and state-building have, in fact, played an important role in the formation of what we now consider indigenous peoples in South America and beyond. In a comparative study of Asian and African colonisation processes, for instance, Murray Li (2010) argues that practices we associate with indigeneity have grown out of attempts by colonial states to 'protect' natives from market mechanisms. More specifically, she emphasises that indigenous people's collective use of land in Asian and African contexts was developed in response to historical dialectics of capitalism and statebuilding (see also Wolf 1957). Colonial powers relied on collective land use as a way to control and exploit local populations-often combined 
with well-intended attempts to protect them against the 'evils' of capitalism. Similar mechanisms were prevalent in South America, where los indios of the Andes-since the 1570s termed Republica de indios-had to contribute with collective labour and the collection and payment of taxes to the Spanish Crown (Platt 1982; Harris 2000). Through these and similar arrangements, los indios of the Andes have continually been (re)constructed as particular kinds of collective subjects (Wade 2017; Ødegaard 2010 ). This kind of dialectical process indicates the importance of considering how indigeneity may at times act as a tool of governance, while at other times serve as a strategy of emancipation and resistance (Murray Li 2010; Postero 2013). Indigeneity, therefore, cannot be seen as referring to a pre-existing, static formation of identity but, rather, as informed by the complex politics and interdependencies of capitalism and state-building as well as to class, language, ethnicity, and racialised hierarchies in particular contexts. Along these lines, it is widely recognised that we need to 'move beyond thinking of indigeneity in the all-or-nothing terms of authenticity and invention, cultural survival and extinction' (García 2005: 6; see also Li 2015: 117), as indigeneity has increasingly come to be seen as a product of the ways in which 'difference is produced culturally and politically' (García 2008: 217). Postero (2013: 108) similarly finds that the representation of - and representatives of -indigeneity emerge from struggles over particular social, cultural, and economic matters during specific moments. The way in which indigeneity and the indigenous are represented has become a central concern, both among indigenous groups and scholars, especially regarding how to and who should represent the indigenous in postcolonial contexts structured by historical power differences. In addition to the heavy influx of external representations of the indigenous in official as well as scholarly discourses, Postero points out that debates about representation must take into account the issue of internal power and differentiating mechanisms in and among indigenous groups: the involvement of indigenous communities in global identity politics, as well as circuits of capital, may significantly increase internal inequalities and power differences and complicate the issue of representation. Without denying either the existence of forms of community prior to the arrival of extractivist projects to indigenous lands or their role in their own definition, it is important to take into account that 'particular, contingent histories of engagement' around extractivist activities can 'yield specific forms of local community' (Ballard and Banks 2003: 297). According to Murray Li (2010: 400), furthermore, we may need to pay 
ethnographic attention to what Mike Davis (2006: 181) calls the 'microcapitalism of the poor', which may be a pervasive feature of people's livelihoods in cities and countryside alike. Against this backdrop, and seeking to understand how extractivism actualises questions of indigeneity and difference, we suggest that the large-scale enclosures of extractive politics should not exclude sensitivity to the microcapitalism enacted by actors in indigenous communities.

As noted, the 1980s is usually considered as marking the rise of a politics of identity and a shift from a previous class-based mobilisation in Latin America and elsewhere. This shift to an emphasis on identity has been seen as part and parcel of an increasing tendency to make moral claims to land and autonomy during a time when class discourse was losing ground (Orta 2004). In this regard, consider Friedman's (1999) somewhat provocative analysis of identity politics and the rise of indigenous movements worldwide from the 1980s onwards. This rise, he argues, was part of a general process of transformation in the world system and the idea of nationhood, characterised by a rapid increase in economic globalisation and the (supposed) weakening of the nation-state. The transformation produced both globalised (cosmopolitan elites) and localised (indigenous and right-wing) identities and formed the basis for political strategies claiming identitybased rights and cultural liberation from the homogenising force of the state (ibid.: 6). Despite the weakening of class-based mobilisation, Friedman suggests that the dynamics of class formation was, nonetheless, a major operator in the continuum between these different forms of identity, with cosmopolitan elites placed at the top of the system and localisers at the bottom. A whole range of contradictory forces accompanied this process, producing class division and asymmetry at all levels, including within indigenous movements. He relates this process of verticalisation to the involvement of NGOs and international funds in the organisation of local movements. This combination of tribal organisation and capital accumulation produced a tribal capitalist mode (from Rata 1997), Friedman argues, with the potential to produce and reinforce class divisions (1999: 10). This argument suggests that the rise of indigenous movements should not simply be understood as (or reduced to) mere opposition to the changing role of the nation-state under economic globalisation but, rather, considered part of it. Meanwhile, the shift to a focus on identity, culture, and recognition, in both popular and scholarly discourse, has provided common ground for various actors seeking to take cultural difference seriously. According to Fraser (2012), however, and as similarly indicated by 
Friedman, the shift to a politics of identity failed to incorporate a critique of capitalism. In Fraser's view, the politics of identity may even be seen to have emerged in a suspect interrelationship with neoliberalism and as intertwined with global capitalist promotion of an emphasis on language and subjectivity at the cost of social egalitarianism (Fraser 2012: 6).

In this volume, we think of the notion of indigeneity as a dialectical construction that is continually made and re-made through historical encounters, government policies, and indigenous mobilisation. Indigeneity can be seen as both the result and the producer of difference. We would like also to point out our hesitation towards what seems to be a tendency, in some debates and studies of indigenous mobilisation, to deal with the issue of difference merely as a discursive construction. This, we suggest, is to sweep the conceptual and political challenge of difference under the carpet. For instance, in a study of the 1990s Latin American social movements discussing their potential for fostering alternative political cultures, Álvarez et al. (1998) noted that we may need to expand our notion of the 'cultural' and recognise that all social movements (whether class-based or identity-based) can be seen as enacting a politics of cultures. While recognising the contested process of the making and re-making of the indigenous, we argue that we should not overlook the very different cosmological and ontological orientations and dynamics that may be at play and which often become particularly salient, given the frictions caused by the expansion of extractive industries. As has been suggested by various scholars debating from premises of the turn to ontology in anthropology, we need to take these differences seriously (see Viveiros de Castro 2015b; Willerslev 2013). Now, with the current mobilisation around environmental concerns and recent developments of a politics of nature in South America, are we experiencing a new shift towards a wider scholarly consideration of a politics of nature with a potential to reflect on the possibilities of other worlds (see Hage 2012; de la Cadena 2010)? How can current indigenous reactions towards extractive industries be understood vis-à-vis, beyond or away from the identity or cultural politics of the 1980s and 1990s? Could these more recent terms of mobilisation, explicitly linked to a politics of nature, be understood as a continuation or extension of the identity politics of the 1980 s and $1990 \mathrm{~s}^{13}$ ? Or is this a form of mobilisation that should be understood in different terms altogether? Could the recent move towards a politics of nature be seen to entail another (more fundamental) form of critique against capitalism than did the identity politics of the 1980s? In sum, how could an interest in ontological questions be reconciled with the epistemo- 
logical scenario of representation, which, historically, has been privileged by identity politics? Could the aim of a permanent decolonisation of thought be considered a radicalisation of the form of critique brought about by identity politics? In this volume, we contend that the recent academic interests in politics of nature as they are reflected in ethnographies from indigenous South America may come from the potential to include a renewed critique of capitalism and modernity.

\section{From a Politics of Identity to a Cosmopolitics of 'NATURE'?}

The boom in extractive industrial endeavours has been accompanied by an intensification of opposition and resistance to large-scale mining and energy extractive projects in response to persisting inequalities, marginalisation, environmental damage, and ecological devastation. Indigenous world- and life-making projects play a central role in many of these initiatives to mobilise against the politics of extractivism ${ }^{14}$; not only as symbols of resistance but also in making political claims and (for some) in the formulation of alternatives to modern politics and capitalism.

In many cases, the current mobilisations around nature or entities of the landscape are spurred by indigenous people's immediate experiences of loss, alienation, and dispossession related to large extractive operations. The issue of loss associated with extractive industries stems from radical changes to people's ways of life, alteration of their environment and means of subsistence (in some cases through forced displacement), and the often disproportional effects of detrimental by-products from extractive projects (Ballard and Banks 2003). Social scientists refer to these areas, where losses are dismissed as necessary for the benefit of economic development, as human and environmental sacrifice zones (Jalbert et al. 2017; Lerner 2010). A range of issues thus arises when considering Amerindian collectives in the context of globalisation and the extractivist 'translation of nature into resources' (de la Cadena 2014) that exacerbates the world ecological crisis. One of these issues is 'the ecologically destructive and socially disruptive forces' that affect those indigenous people who are struggling to deal with these processes on their own terms (High 2015: 101, 170).

There has been a shift in the narrative framing of indigeneity in the current era, especially in countries such as Bolivia and Ecuador, as suggested by Fabricant (2013). She notes that in Bolivia, in the 1980s and 1990s, 
indigeneity was a language of resistance used for claiming rights as well as reclaiming lands from the oligarchy and transnational corporations. With the government of Morales, the narrative framing of indigeneity has shifted with a broadening of indigenous cosmovision (worldview) to a resource for saving the planet from climate change. Fabricant discusses this as a narrative of indigeneity that Morales has drawn upon in international forums, calling for the adoption of so-called indigenous notions of sumak kawsay (in Quechua) or suma qamaña (in Aymara), usually translated as living well (ibid.; see also Merino 2016). One of the most visible expressions of this shift to a politics of nature may be at the crossroads between indigenous mobilisation, international environmentalism, state governance, and ontologically inflected ethnographic studies. Postero writes that at this meeting of local and global environmental concerns, indigeneity is (once again) made into both a language of governance, a legitimating discourse for the state, and a language of rights employed by citizens demanding access to state resources (2013: 114; see also Postero 2017: 21). This coupling of indigenous notions of sumak kawsay and global environmentalism may produce a range of new dilemmas and contradictions related to what an essentialised notion of indigeneity may mean for large numbers of urban indigenous people, for instance, who might not necessarily oppose resource extraction as such (Fabricant 2013). In this regard, while the Bolivian government's statements about climate change may suggest a clear opposition between indigenous values such as sumak kawsay and capitalism (see also Schavelzon 2016: 121-122), we need to recognise the differing and often conflicting interests among indigenous groups (Fabricant 2013; see also Postero 2013: 113; High 2015 ), their different relations to the extractive industries, and their provisional uses of particular conceptual resources in specific political contexts (Cepek 2016). As noted by Postero, indigenous people remain at the centre of disagreements over the national development models based on natural resource extraction, new forms of government, and relations between the central state and local communities. We are, therefore, compelled to explore the complex ways in which indigeneity is contested and represented in debates over the extractive industry.

Against this backdrop, it is worth asking how the globalisation of discourses on ecological degradation and climate change (through NGOs, governments) serves to inform and spur indigenous mobilisation around the so-called nature. In other words, how is indigenous politics of nature related to other kinds of mobilisation and protests and to international 
environmental discourse more widely (see Li 2015; Postero 2013; Fabricant 2013; see also Li and Paredes Peñafiel, this volume)? How can we relate the simultaneity of different mobilisations concerning 'nature' to the radical alterity of indigenous ontologies? Considering the recent mobilisation against extractive industries in many countries, Li's ethnography of the mobilisation around particular entities of the landscape documents how such mobilisation sometimes crosscuts conventional groupings related to class or ethnic identity, involving peasant and indigenous communities, NGOs, and transnational environmentalists. Li reminds us that actions often defined as indigenous knowledge or tradition are not fixed entities, since arguments that appeal to such notions are made from localglobal encounters (2015: 220). For instance, in Porcón, one of the communities where she worked, Li illustrates how it took a proposed mining project-with the threat of open pits, chemicals, and altered water courses - to actively produce the 'indigeneity' of her interlocutors and to make their relationship to a sentient landscape politically visible and significant in the present (ibid.: 116-117). This is an important point, but should not, in our opinion, undermine the gains of ethnographic expositions to Amerindian ontological patterns and alternative compositions of the world (see Pazzarelli 2013; Alberti et al. 2011; Nielsen 2016; Rivera Andía 2005a, b, 2006, 2008; Fortis 2014; Alberti 2014; Harris 2000; Orta 2004), particularly when both approaches could actually benefit and inform each other.

Reflecting on the interconnectedness with worldwide discourses on rights and recognition, Steur (2014) notes that indigenous movements often rely on a contradictory mix of epistemologies - of legally and scientifically prescribed identification, popular revisioning of historical memory, references to differing political ideologies, and attempts to appeal to middle-class imaginaries of indigenousness (see also Li 2015; Postero and Fabricant, this volume). Against this backdrop, and referring to indigenous movements in India, Steur (2014: 2) argues that it would be a mistake to read indigenous mobilisation only in terms of an ontological critique of Western modernity. She identifies problems in what she considers a recent tendency in studies of indigenous movements to reduce them to a question of 'ontological critique' and, more importantly, to engage with the question of capitalism only to the extent to which it represents yet another problem of Western ontology (see also Bessire 2014). This tendency, which some authors consider a price worth paying (Candea 2017), invites the risk that the historical, real, and relational process of capitalism 
is sidestepped, culturalised, or even reduced to Western myth (or ontological dualisms). In order to understand the emergence and, not least, the timing of indigenous movements and politics, Steur argues that we need to sharpen our understanding of how capitalist mechanisms work themselves out and are renegotiated in people's everyday working lives, organised collectivities, and socially reproductive activities (Steur 2014: 2). In accordance with this point by Steur, our volume focuses on indigenous responses to extractive industries in an attempt to reveal how these endeavours play out in everyday lives, and, further, we explore how ontological differences might inform these processes and responses. We consider that the examination of capitalist expansion and extractivism could benefit from a focus on the significance of ontological difference to understand how these processes are dealt with, lived, negotiated, and altered by local indigenous populations. As noted by Blaser (2004), while indigenous communities all over the world have opposed many developmentalist agendas, their agendas are themselves emergent rather than a mere reaction to other agencies.

Our concern with cosmologies and ontologies in this volume certainly does not entail an assumption that indigenous world- and life-making projects necessarily take the form of opposition or resistance to extractive endeavours. In fact, the volume is not limited to the issue of protest, mobilisation, or politically motivated actions; we are also interested in rather ambiguous situations where ontological principles are made relevant as part of indigenous peoples' way to make sense of their life-making projects alongside extractivist endeavours. In this respect, we build on Blaser's (2004) focus on how people sustain life projects that are embedded in local histories and visions of the world and the future that are distinct from those promoted by state and markets. Underlining how indigenous communities do not necessarily resist development, Blaser argues that struggles to pursue life projects, often 'premised on densely and uniquely woven "threads" of landscapes, memories, expectations and desires', may be at least equally important to chronicle and analyse (Blaser 2004: 26). Along these lines, our intention is to explore the dilemmas, frictions, and uncertainties arising from the complex coexistence of a global hegemonic notion of nature as resource on the one hand and various Amerindian socionatural formations on the other hand. We are thus required to uncover the variety of ways in which indigenous ontogenies ${ }^{15}$ are configured and re-accommodated in people's attempts to resist, to make sense of, or simply survive in contexts of extractive industry activity in South America. Hence, our wish 
to show the significance of different life- and world-making projects in everyday lives. We find this to be a useful approach particularly in a context of ongoing and heated debates about a tendency in the ontological turn in anthropology to fix differences and to restrict itself to the domains of abstract and generalising discussion of rigid 'ontological schemes' (Vigh and Sausdal 2014). To elude a presupposition of ontology as worlds separated by incommensurable differences, we propose to consider the expansion of extractive industries in South America (and indigenous peoples' attempts to deal with it) through concepts such as ontological dynamics (see Remme 2016) or ontogénies (Ingold in Descola and Ingold 2014). An emphasis on ontological dynamics in such encounters involves a concern with the emergence of boundaries and entities as an effect of specific practices, especially attempts to stabilise and contain the entities and boundaries that extractivism makes visible, uncertain, or nonexistent.

\section{Final Thoughts on Life Projects and Turbulences}

Extractivism stands out among the remarkable challenges associated with ideologies and processes of globalisation that Amerindian collectives of South America are facing. Taking into account this encounter between different perspectives, ideologies, and praxes-by no means new but in many cases affected by a sort of acceleration (Brightman et al. 2016:2) —scholars concerned with indigenous societies have had to broaden the scope of their reflections and adopt new analytical tools. In this context, some scholars have aimed to show ethnographically how 'the modern world or ontology sustains itself through performances that tend to suppress and or contain the enactment of other possible worlds' (Blaser 2009: 16):

[C]ommoning comes at the cost of subordinating one set of practices to the other through "same-ing"-that is, an equivalence is proclaimed (and accepted) where a divergence is actually operative. The consequence is that dominant practices can eventually operate as if the subordinate ones were irrelevant to the constitution of the commons (Blaser and de la Cadena 2017: 190).

Suppression and subjection (Escobar 2016: 15) are also implicit in the imposition described as part of a war of worlds: "the world ("as we know it") is imposed in myriad ways on other peoples' worlds (as they know them), even as this hegemonic world seems to be on the brink of a slow, painful and ugly ending' (Viveiros de Castro 2015b; see also Schavelzon 2016). ${ }^{16}$ 
Along these lines, some scholars insist that culture, as opposed to nature, would not be sufficient to understand the challenge represented by contemporary indigenous politics and the quest to promote indigenous rights (Blaser 2009; de la Cadena 2010, 2015). The challenge of this 'transition to who knows what' (Gilbert in Haraway et al. 2016: 541) concerns an ontological politics, a cosmopolitics, by which different possible entanglements between humans, nonhumans, and places become occasions for ethical controversy (Wardle and Schaffner 2017: 9-24). Contemporary indigenous movements fighting against the predatory policies of multinationals are concordantly perceived as a way to re-establish the sovereignty that humans and nonhumans exercise over themselves (Descola 2014b: 55).

Previous attempts to conceptualise the involvements of indigenous peoples in a globalised economy have tended to focus on their relationship with external extractivist agents in terms of individualism, monetisation, inequality, and resistance produced in the relation to capitalist modes of production. Seeking to expand from these conceptualisations, we wish to explore how Amerindian groups can maintain their ability to be part of a localised (place-based) community in a socially legitimate manner while simultaneously facing the challenges produced by, for example, the forceful expansion of a monetary economy and wage labour accompanying the extractivist industries. We intend neither to deny the depth of the transformations of indigenous life projects caused by extractivism nor assert its ineluctability or radicalness. Instead, we would like to test the possibility that changes in Amerindian collectives could follow indigenous patterns identified across diverse Amerindian regions (Fausto 2012 [2001]; Gutiérrez 2001; Rivera Andía 2005a, b, 2008; Erikson 1986, 1999; Santos-Granero 2009; Ortiz Rescaniere 1999; Pitarch 2003; Viveiros de Castro 2004a, 2011). How do the different strategies used by indigenous groups and communities to incorporate the external otherwhich is often seen as an indispensable feature of the making of the self (Viveiros 2004a: 475; High 2015)—operate in extractivist contexts?

Further, how could we reintroduce a kind of morality into our relationships with nonhuman environments (Hornborg 2006: 25), when we have for centuries deprived nature of morality (Callicott 1989, Berkes 2005, Kapfhammer 2012), historicity, and 'the inner narrativity that is part and parcel of being in the world' (Latour 2014: 13)? This ethical issue raises the question of whether the ontological turn blurs the other's suffering and devastation (see Escobar 2016: 23). Or, put differently, is this anthropology of ontology... 'with the potential to revolutionise anthropological practice and even save the planet from ecological apocalypse' (Scott 2013: 860) 
indeed hampering much needed situated analyses of afflictions and struggles? Would those proposals in which indigenous people are deemed as an environmental remedy to the behaviour of the West (Killick 2015) constitute nothing but a 'problematic form of speculative futurism' (Bessire and Bond $2014 \mathrm{c}$ )? Moreover, is this a sort of futurism where some life-making projects have priority over others, thereby doing a disservice to the complexity of indigenous ways of living (Bessire 2014: 228; Killick 2015; see also Kapfhammer 2012: 149-152)? Facing these issues, the chapters compiled in this volume aim to provide descriptions of South American life projects that are being troubled, subdued, ignored, or 'actively produced as non-existent' (Escobar 2016: 15) by current policies of extractivism (Schavelzon 2016). We seek to address the unfolding of indigenous life projects in extractivist contexts in line with the proposition of an ontographic method (Holbraad 2009), as a way of avoiding conceptual imperialism and the imposition of our own categories and assumptions. Without dismissing conceptual reflexivity, we want to address and describe people's life projects more specifically in contexts of extractivism, including their sufferings, adversities, and struggles. We strive to avoid any type of prophetic conceptual futurism (Bessire 2014) - predefining, for example, indigenous peoples as hostages of some notion of indio ecologico-and, rather, pay attention to the coercive or punitive actions related to ongoing extractivism. Instead of persisting to simply apply our own pre-conceptualisations about extractivism's specific effects, however, we try to explore indigenous experiences of loss and suffering as a function of the (imposed) inability to gain, realise, or obtain one's own life project. We would like this to be our contribution to the literature as well as to debates about extractivism in South America, by showing the relevance of conceptual reflexivity to produce ethnographic accounts of extractivist Amerindian contexts' asymmetry and suffering. We draw on various contributors to the debates on the ontological turn and their emphasis on ethnographic conceptual reflection (see Holbraad 2014) while suggesting that an 'ontological opening' (de la Cadena 2014) to people's urgent circumstances (Bessire 2014) may also contribute to ways of thinking otherwise.

\section{The Chapters of This Book}

The chapters of the volume address, within various ethnographic contexts and from different points of view, the issues, controversies, and questions of three broad topics currently relevant when dealing with extractivism in 
Amerindian South America: the reactions to, access to, or deprivation of the wealth linked to extractive industries (Guzmán-Gallegos, Penfield, Krøijer and Ødegaard); the conceptualisations and practices associated with territory and land ownership (Stensrud, Rivera Andía and Brightman); and the political reactions of indigenous peoples through the evolution of activism and the concept of indigeneity ( $\mathrm{Li}$ and Paredes Peñafiel, Postero and Fabricant).

Part I, Flows, Wealth, and Access, considers the Kichwa people in the Upper Tigre River near the frontier between Peru and Ecuador (GuzmánGallegos), the Sieko-pai (or Secoya) of northeastern Ecuador (Krøijer), the Sanema of Venezuelan Amazonia (Penfield), and the Andean smugglers working in the frontier between Peru and Bolivia (Ødegaard). In each of these cases, the authors highlight local indigenous communities' strategies to face asymmetries and turbulences created by extractivism in their worlds.

María Antonieta Guzmán-Gallegos' chapter examines the diverse and changing ways in which the Kichwa people relate to the leftovers of oil extraction in their everyday lives in the Upper Tigre River. She explores different types of abandoned oil installations and toxic waste that are part of landscapes of rubble saturated by ruination processes. The chapter shows how rubble and ruination embody the expansion of extractive capitalism in northern Peruvian Amazonia. This expansion entails a persistent disregard, both corporate and state, of the Kichwa people's ways of life, a disregard which constitutes them as disposable and the places they inhabit as sacrifice zones. It suggests that the Kichwa's current attempts to take control (a topic also addressed by Krøijer, and Rivera Andía) over abandoned oil installations and the remaining toxic wastes are acts of contestation. Their attempts at control, the author argues, are a rejection of the negation of their existence. The chapter shows that these attempts are, at the same time, an actualisation of divergent notions of ownership and their enactments (a topic also addressed by Brightman, Stensrud and Rivera Andía). Guzmán-Gallegos suggests that this actualisation multiplies the object owned. For the Kichwa, owned land is both the result of acts of care and transformation as well as legally titled area. While the first form of land ownership manifests and is a product of the relations of the people living in a place, titled land materialises their relationship with the state. The author proposes that, through multiplication of what is owned as well as the articulation of distinct enactments and understandings of ownership, the Kichwa seek to redefine the overwhelming asymmetries that characterise their long-standing relations with the state and other nonindigenous actors. 
The chapter by Stine Krøijer considers the devastating social and environmental consequences of the constant penetration of the extractive frontier into indigenous territories in northeastern Ecuador. She explores the strategies followed by the Sieko-pai (formerly known as Secoya) living in or near oil fields for dealing with the transformations suffered by their world during decades of oil extraction. How do they, in fact, maintain a sense of control over their lives in the encounter with the extractivist imperative in its Ecuadorian version? Documenting the Sieko-pai's considerations about the disruptions-caused by the incorrect treatment of oil and blood-of positive 'flows' between powerful others (from jaguars to private companies) and indigenous territories and bodies, Krøijer pursues the analytical implications of a specific enquiry concerning indigenous life projects in a world saturated by extractivism. Her chapter contributes to current debates around the ontological analogy between oil and the socalled subterranean spirits' blood without amounting to either an indigenous submissive acceptance or a heroic resistance of the circumstances externally inflicted on them. Instead, the author shows us that living with oil extraction expresses the Sieko-pai's flexible ability to control a set of transformations in their world with their own life-project agendas.

The chapter by Amy Penfield explores more understated and multifaceted responses to extractivism that differ from the common depictions of indigenous resistance to extraction. These resounding tropes, while accurate representations of extraction in many cases, often eclipse the ways in which indigenous responses may be more layered and perhaps even interwoven with their social and cosmological ethos. Drawing on field research among the Sanema of Venezuelan Amazonia, Penfield demonstrates how extractivism and its products, as well as associated wealth are integral to the Sanema livelihood and transforming notions of personhood in unanticipated ways. Their unique location in the resource-rich forests of the Venezuelan petro-state means that extraction has a twofold bearing on their lives: first, as an abstract phenomenon in the form of oil wealth dispensed to citizens and, second, as the intimate reality of gold mining in their territory. Both forms of extraction have manifold and significant impacts. Contrary to the perception that incorporation into the extractive economy brings with it individualism and social degeneration, Penfield's chapter vividly shows how the wealth associated with extraction may also facilitate sociality, reciprocity, and compassion among kin (a similar situation is described in Ødegaard's chapter). Wealth, among the Sanema, is found in human relationships, not self-interest. 
The chapter authored by Cecilie Vindal $\varnothing$ degaard leaves the rural settings of most of the chapters for an urban one, describing issues related to those of Krøijer and Penfield. Ødegaard focuses on the smugglers of fuels who operate in the frontier between Peru and Bolivia. Despite their strong Aymara and Quechua origins, the contrabandistas have usually been addressed by ethnographies more interested in economic 'informality' in South America (Goldstein 2016) than in Amerindian worldviews. Instead, Ødegaard considers the labour of contrabandistas as a redirection of commodities from official circuits of distribution (in this case, fossil fuels) and explores how the practices of contrabandistas contribute to subsume wealth to particular modes of sociality, including relations with market colleagues, kin, and earth-beings. Translating from one form of value accumulation to another, more redistributive form, these actors' life projects are aimed at recreating local forms of relatedness. Both redistribution and translation here entail a semiotic multiplication involving different systems of meaning that exceed what the author calls the capitalist system of commensuration: a hegemonic, modernist production of equivalence supported by narratives of progress and development that usually accompany extractivism in South America. By exploring commodity flows as well as contrabandistas' relations to the powerful earth-beings of the Andean landscape, Ødegaard reveals the partial connections of locally embedded worldings and dominant extractive practices. As in other chapters of this book, and without dismissing the consequences of accumulation and inequality in the Andes, Ødegaard finds that resistance to extractivism is not absolute. Instead, the author describes a set of strategies used to deal with the forces and wealth of extractivism while paying attention to the relational and cosmological aspects of wealth and its mediation; here termed accumulation by diversion.

In Part II, Extractivism, Land, Ownerships, Stensrud writes about the Quechua indigenous communities in the Arequipa highlands (Peru). Rivera Andía offers an ethnographic account of the Cañaris people (also in Peru but around 2000 kilometres north of Arequipa). And, finally, Brightman describes the case of the Trio in Suriname. These three chapters consider the issue of indigenous conceptualisations and assertions of ownership and management of lands in contexts that are not often addressed directly in the literature on extractivism: 'spectral' mining projects, megaprojects of channelling water for agroindustry, and hydroenergy and, last but not least, quantification of biodiversity and forest carbon.

Astrid Bredholt Stensrud suggests that earth-beings in the southern Peruvian context are not necessarily or deliberately invented as an indigenous strategy to stop extractivism, but, rather, form facets of relationships 
that are continuously nurtured as part of ongoing local life projects. While most studies focus on the boom in oil, minerals, and logging, Stensrud's chapter explores another form of extractivism which is growing in importance in Peru and elsewhere: the extraction of economic value from water in infrastructural mega-projects for the damming and channelling of water. She examines the implications of the Majes Irrigation Project for Quechuaspeaking farmers and how they make claims to the water located within their lands. More specifically, she explores the conditions that make these land claims possible and how they are connected to notions of belonging and ownership that emerge from particular ontological compositions of water, mountains, personhood, earth-beings, and other nonhuman entities. These compositions and the life projects associated with them, Stensrud argues, conflict with the extractivist and modernising project of colonising water by turning it into an economic resource.

The chapter by Juan Javier Rivera Andía explores the terms by which the Cañaris Quechua-speaking people of the northern Peruvian highlands establish their relationship with the 'land' in a local context marked by extractivism. The extraction of resources implies taking the local places inhabited by the Cañaris people as an inert 'natural' land-object that is susceptible to being used and appropriated without much attention to what a president of Peru recently called 'absurd ideologies'. The author examines the conflicting ways in which land is experienced and understood in an area with evergrowing social conflicts linked to mining in Peru. Leaving open the possibility of the radically distinct multiplicity of a 'living' environment with whom humans relate in 'social' terms (illustrated also by Stensrud and by Ødegaard) that exceeds but is entangled with modern European conceptions of private property, he describes local practices and conceptions concerning the production, access, and administration of the land (also addressed by Brightman). What emerges then is a nonhuman entity that is less 'natural' and 'indigenous' than what is usually expected in this type of ethnographic account: the Iglisya (Quechua term that comes from the Spanish iglesia, church). This indigenous building not only represents the land but constitutes it; it is the land (or what we could expect to find in Cañaris when arriving with such a concept in mind). Distant from combative public speeches, environmental activism, or 'classic' Andean nonhuman beings, the prevalence of the material, collective, and nonverbal aspects of the relationships that produce the Iglisya, might, in fact, constitute a truly cosmopolitical and powerful fighting device to contend on their own terms (which Krøijer also addresses) with the threat currently suffered by the Cañaris. In Cañaris, 
extractivism is affecting not only the rights of an indigenous people but a particular way to compose the world, a form that should be taken into account in any serious attempt to define key concepts in Andean ethnography (such as 'communal lands' or comunidad campesina).

Marc Brightman's chapter discusses the works of international environmental NGOs that seek to conserve biodiversity among native Amazonian people in Suriname as a nonconventional form of extractivism. As recognised in various cases, these efforts are increasingly inserted in a globalising modern worldview associated with refined techniques for the monitoring and (more importantly) the quantification of biodiversity and forest carbon. Addressing the significances for the Trio of this relatively new economic, political, and ideological context promoted by the liberalisation of conservation, the author explores how indigenous conceptualisations (for instance, those regarding land ownership) contrast and entangle with the perspectives of technical and governmental agents intervening in their territory. Thanks to this comparative view, Brightman allows us an ethnographically informed insight into the different sets of distinctions and continuities between carbon and biodiversity accounting and other more conventional forms of extractivism taking place in indigenous worlds.

Part III, Indigeneity, Activism, and the Politics of Nature, is somewhat less interested in debates on ontology and comprises two co-authored chapters. The first, by Li and Paredes Peñafiel, discusses central leaders of anti-mining activism in both Peru and Brazil. The second study, by Fabricant and Postero, focuses on the conflicts around the construction project of a highway that traverses the Bolivian Isiboro Sécure National Park and Indigenous Territory (abbreviated as TIPNIS in Spanish). Both chapters offer detailed descriptions of events known nationally and internationally and that are still evolving.

The chapter by Fabiana Li and Adriana Paredes Peñafiel explores the manifold interconnections between community-based resistance and national, as well as international activist networks. Focusing on organised resistance to mining activity (including indigenous peoples but also other actors) in Peru's northern highlands (neither geographically nor culturally far from the region studied in Rivera Andía's chapter), the authors trace the opposition to a proposed mining project (the Conga campaign) and the dynamics that arise when local activism travels through documentaries, news media, lawsuits, and networks. Analysing the international reverberations of the conflict and activist efforts, they describe the emergence of key leaders-particularly female ones - and how they and media actors represent the conflict. In so doing, they explore the translation of these (media) representations from the 
Peruvian context to a situation of increasing open resistance among scholars and middle-class activists to resource extraction in Rio Grande del Sul, Brazil. The authors document how this resistance may reverberate elsewhere and discuss its potential to challenge the logic of extractivism by opening up a space for alternative life-making projects that both transcend and communicate between connections to a local landscape.

Addressing how indigeneity is actualised in social mobilisation, Nicole Fabricant and Nancy Postero examine the ways in which indigeneity is performed in Bolivia. Focusing on current protests against the construction of a highway through indigenous territories, they consider how performance can play a central role in what they call moral reflection about indigeneity, gender, and the articulation of alternative social worlds. Using the concept of 'ethical substance' (Povinelli 2012), the authors explore how, through performance, indigeneity serves as a central site of moral reflection and conduct in their particular ethnographic settings. In so doing, they show how protests and performance also call into question the legitimacy of the Evo Morales government's claim to stand for all indigenous peoples. The chapter demonstrates how distinct actors may claim access to indigeneity, and that multiple actors perform indigeneity to push through their own ethical and political agendas.

In sum, the third section of this book deals with widely held notions and practices linked to activism and indigeneity in current (and different) South American national scenarios. Extractivism is here expressed either directly, as in an open-pit mine, or indirectly, as in a highway project. In contrast to this section, the first two parts of the book explore local indigenous situations. The second part deals with relatively less frequently described forms of extractivism: the conflicts over an extraction yet to come in the Andes, the fight to control a substance as scarce as water in relation to an agroindustrial project, and the not so visible consequences of quantification of carbon and biodiversity in forest in Amazonia. In all these cases (and also in other sections of the book, although to a varying extent), the chapters highlight the diverse entanglements of humans and nonhumans and the reconceptualisation that these entanglements require. Finally, this brings us back to the first part's descriptions of the diverse strategies indigenous peoples and urban proletarians use to face extractivism in their life-making projects in South America. Here, humans and things (such as rubble, abandoned wells, irrigation canals, ritual offerings, and gas cylinders) are not only entangled but might also mutually constitute each other in the mist of the asymmetric turbulences emerging from South American extractivism. 


\section{Notes}

1. We build here on Blaser's (2004) focus on how people sustain life projects that are embedded in local histories and visions of the world and the future distinct from those promoted by state and markets.

2. As is well known, animism is one of the oldest concepts in anthropology, representing the 'century-old problem [of] why people animate what we regard as inanimate objects' (Bird-David 1999: 70). In fact, ethnologists' efforts to understand this 'bizarre scandal' (Kohn 2009: 136) could be traced at least to the seminal work by Edward B. Tylor (1871) who explained 'animism' in accordance with David Hume's thesis in Natural History of Religion (Brightman et al. 2012: 3) and the German protovitalist Ernst Stahl (Halbmayer 2012: 9). After more than a century, this attribution of a social character to relations between humans and nonhumans is traditionally understood as configuring a world in which the default form of interaction between beings is modelled on that which occurs between subjects (Costa and Fausto 2010: 94).

3. Debates about the turn to ontology are often complicated-or perhaps enriched - by the variety of definitions and uses of the term ontology. Most of its proponents attempt to decentralise what being human entails and apply the porous or negotiated nature of its boundaries to other species and materialities (Bertelsen and Bendixsen 2016: 7). For instance, Scott (2013: 859) defines ontology as 'the investigation and theorization of diverse experiences and understandings of the nature of being itself'. Our discussion of the question of ontology in this introduction is by no means intended to provide an exhaustive account of the contributions and debates in its wake, as comprehensive overviews of these debates have been provided elsewhere (e.g., Holbraad and Pedersen 2017; Kohn 2015; Alberti et al. 2011; Bertelsen and Bendixsen 2016).

4. Rivera Andía's translation.

5. Rivera Andía's translation.

6. The fall of prices was caused partly by US oil sands production. In the period 2011-2015, a nearly 50 per cent fall in the prices of raw materials and energy (oil, gas, carbon) directly affected countries, such as Bolivia, Colombia, Ecuador, Venezuela, Chile, and Peru, that export hydrocarbons and metals.

7. This approach allows us to include, along with mining and oil extraction, fishing and cocaine production among extractivist activities in South America. It should be recognised that, either because of tacit consideration as a nonconflicting activity (as fishing) or as too conflictive (as narcotraffic), both are social, political, and economic extractivist activities that are still not being as closely studied as, for instance, 'petro-cultures' (e.g., Cepek 2016). 
8. Based on the International Labour Organization Convention 169 and the Native Communities Law which have been signed by several governments in South America between 1991 and 2008, through which states are expected to recognise indigenous land rights, and which later, at least on paper, have been reinforced by laws pertaining to participation and prior consultation.

9. Because of the shift towards a capital-intensive dynamic instead of a labourintensive one.

10. This form of detection and inclusion of entities such as spirits of the mountains in current anthropological ethnographies has been labelled as a version of the ontological turn called 'alternative ontology': 'a highly influential theoretical intervention in political and political-economic anthropological debates' (Holbraad and Pedersen 2017: 52) that nevertheless 'still operate[s] by grounding the possibility of political difference in a prior story of how the world(s) must work' (Holbraad and Pedersen 2017: 54; see also Mol 1999; Latour 2014).

11. A whole range of issues could be drawn from this single question. What are, for instance, the implications of addressing it from outside of the Global South or, more precisely, from those 'rich nations' which Chakrabarty considers guilty of 'the current crisis' (2009: 216)? How to compose a common world thinking, as Stengers (2005) puts it, 'in the presence of' those most negatively affected by extractivism from a 'North' sometimes imagined as free of the conditions and consequences of the inequalities that characterise the South American scenarios described in this book? Finally, and regarding only the domain of the production of anthropological knowledge, how could the asymmetries between hegemonic and marginal narratives and groups taking place in different parts of the world (Narotzky 2010) be put into a productive dialogue?

12. Being defined through their historical use of and belonging to a certain area and the rights attached through collective use of this land, indigenous peoples are further ascribed cultural specificities that often have bearing on their practices related to the land.

13. Indigenous mobilisation in this period certainly included land and titling as part of their claims for cultural rights. We should also be aware that this periodisation may overly simplify struggles that were in fact multifaceted and entailing not only questions of language and culture (but whose acknowledgement mainly in terms of language and cultural expression may have been in the interest of national governments).

14. The same could be said to happen against the developing clean energy projects driven by the increasing demand for energy in South America (Howe 2015). 
15. We take this term from Tim Ingold, who uses it in several works 'to describe how form, rather than being applied to the material, is emergent within the field of human relations. This is neither making nor growing, but a kind of making-in-growing, or growing-in-making' (Ingold and Hallam 2014: 5). Or put differently: 'What if we were to reverse our priorities, and subsume making under growth? Would not the concept of agency then take second place to that of animacy, as embodiment would take second place to ontogenesis, and being to becoming?' (Ingold and Hallam 2014: 17; see also Ingold 2013: 95-97; Descola and Ingold 2014).

16. Similar positions have been delineated by Latour: 'There is no such a thing as a "common world." The issue of vegetable oil fuels is a war' (Latour 2015, authors' translation). 'War is infinitely more likely than contract' (Latour 2014: 5). In the case of scholars working on South America, this position resonates with those of Escobar referring to the 'struggles for the defense of territories and difference' (2016: 13) and Schavelzon regarding the project of a Bolivian constitution (2016: 126).

\section{REFERENCES}

Acosta, Alberto. 2011. Extractivismo y neoextractivismo: Dos caras de la misma maldición. In Más allá del desarrollo, ed. M. Lang and D. Mokrani, 83-120. Quito: Abya Yala y Fundación Rosa Luxemburg.

- 2013. Extractivism and Neoextractism: Two Sides of the Same Curse. In Beyond Development: Alternative Visions from Latin America, ed. M. Lang and D. Mokrani. Quito: Abya Yala y Fundación Rosa Luxemburg.

Alberti, Benjamin. 2014. Designing Body-Pots in the Formative La Candelaria Culture, Northwest Argentina. In Making and Growing: Anthropological Studies of Organisms and Artefacts, ed. Elizabeth Hallam and Tim Ingold. Farnham: Ashgate Publishing.

Alberti, Benjamin, Severin Fowles, Martin Holbraad, Yvonne Marshall, and Christopher Witmore. 2011. "Worlds Otherwise": Archaeology, Anthropology, and Ontological Difference. Current Anthropology 52 (6): 896-912.

Álvarez, Sonia E., Evelina Dagnino, and Arturo Escobar. 1998. Cultures of Politics, Politics of Cultures: Re-envisioning Latin American Social Movements. Colorado/Oxford: Westview Press.

Ansión, Juan. 1987. Desde el rincón de los muertos: el pensamiento mítico en Ayacucho. Lima: GREDES.

Arsel, Murat, Barbara Hogenboom, and Lorenzo Pellegrini. 2016. The Extractive Imperative and the Boom in Environmental Conflicts at the End of the Progressive Cycle in Latin America. The Extractive Industries and Society 3: 877-879. 
Ballard, Chris, and Glenn Banks. 2003. Resource Wars: The Anthropology of Mining. Annual Review of Anthropology 32: 287-313.

Bebbington, Anthony, and Denise Bebbington. 2012. Post-What? Extractive Industries, Narratives of Development and Socio-Environmental Disputes across the (Ostensibly Changing) Andean Region. In New Political Spaces in Latin American Natural Resource Governance, ed. H. Haarstad. London: Palgrave Macmillan.

Bebbington, Anthony, and Jeffrey Bury, eds. 2014. Subterranean Struggles: New Dynamics of Mining, Oil, and Gas in Latin America. Austin: University of Texas Press.

Berkes, Fikret. 2005. Traditional Ecological Knowledge. In Encyclopedia of Religion and Nature, ed. Bron Taylor. London: Thoemmes Continuum.

Bertelsen, Bjørn Enge, and Synnøve Bendixen, eds. 2016. Critical Anthropological Engagements in Human Alterity and Difference. London: Palgrave Macmillan.

Bessire, Lucas. 2014. Behold the Black Caiman: A Chronicle of Ayoreo Life. Chicago: University of Chicago Press.

Bessire, Lucas, and David Bond. 2014a. Ontological Anthropology and the Deferral of Critique. American Ethnologist 41: 440-456.

- 2014b. Ontology: A Difficult Keyword. Virtual Issue, Ontology in American Ethnologist, 1980-2014. http://onlinelibrary.wiley.com/journal/10.1111/ (ISSN)1548-1425/homepage/virtual_issue_ontology.htm. Accessed 19 Mar 2016.

- 2014c. The Ontological Spin. Cultural Anthropology Online. http://www. culanth.org/fieldsights/494-the-ontological-spin. Accessed 19 Mar 2016.

Bird-David, Nurit. 1999. 'Animism' Revisited: Personhood, Environment, and Relational Epistemology. Current Anthropology 40 (1): 67-91.

Blaser, Mario. 2004. Life Projects: Indigenous People's Agency and Development. In In the Way of Development: Indigenous Peoples, Life Projects, and Globalization, ed. M. Blaser, H.A. Feit, and G. McRae. London/New York: Zed Books.

- 2009. The Threat of the Yrmo: The Political Ontology of a Sustainable Hunting Program. American Anthropologist 111 (1): 10-20.

Blaser, Mario, and Marisol de la Cadena. 2017. The Uncommons: An Introduction. Anthropologica 59: 185-193.

Blaser, Mario, Harvey Feit, and Glenn McRae, eds. 2004. In the Way of Development: Indigenous Peoples, Life Projects, and Globalization. London/ New York: Zed Books.

Boellstorff, Tom. 2016. For Whom the Ontology Turns: Theorizing the Digital Real. Current Anthropology 57 (4): 387-407.

Bridge, Gavin. 2004. Mapping the Bonanza: Geographies of Mining Investment in an Era of Neoliberal Reform. The Professional Geographer 56 (3): 406-421.

- 2008. Global Production Networks and the Extractive Sector: Governing Resource-Based Development. Journal of Economic Geography 8: 389-419. 
Brightman, Marc, Vanessa Grotti, and Olga Ulturgasheva, eds. 2012. Animism in Rainforest and Tundra: Personhood, Animals, Plantsand Thingsin Contemporary Amazonia and Siberia. New York/Oxford: Berghahn Books.

Brightman, Marc, Carlos Fausto, and Vanessa Grotti, eds. 2016. Ownership and Nurture: Studies in Native Amazonian Property Relations. New York/Oxford: Berghahn Books.

Bunker, Stephen G. 1984. Modes of Extraction, Unequal Exchange, and the Progressive Underdevelopment of an Extreme Periphery: The Brazilian Amazon, 1600-1980. American Journal of Sociology 89 (5): 1017-1064.

Callicott, J. Baird. 1989. In Defence of the Land Ethic: Essays in Environmental Philosophy. Albany: State University of New York Press.

Candea, Matei. 2014. The Ontology of the Political Turn. Cultural Anthropology. https://culanth.org/fieldsights/469-the-ontology-of-the-political-turn. Accessed 18 Jan 2018.

- 2017. We Have Never Been Pluralists: On Lateral and Frontal Comparisons in the Ontological Turn. In Comparative Metaphysics. Ontology After Anthropology, ed. P. Charbonnier, G. Salmon, and P. Skafish. London/New York: Rowman \& Littlefield.

Canessa, Andrew. 2006. Todos somos indigenas: Towards a New Language of National Political Identity. Bulletin of Latin American Research 25 (2): 241-263.

Caro, Tim, Jack Darwin, Tavis Forrester, Cynthia Ledoux-Bloom, and Caitlin Wells. 2012. Conservation in the Anthropocene. Conservation Biology 26 (1): $185-188$.

Carstensen, Jeppe. 2014. Capturing the Anthropocene: Sensory Ethnography in Anthropogenic Biomes. Master's thesis, Lund University.

Cepek, Michael. 2016. There Might be Blood: Oil, Humility, and the Cosmopolitics of a Cofán petro-being. American Ethnologist 43 (4): 623-635.

Chakrabarty, Dipesh. 2009. The Climate of History: Four Theses. Critical Inquiry 35 (2): 197-222.

Chiasson-LeBel, Thomas. 2016. Neo-Extractivism in Venezuela and Ecuador: A Weapon of Class Conflict. The Extractive Industries and Society 3: 888-901.

Corsín Jiménez, Alberto, and Rane Willerslev. 2007. 'An Anthropological Concept of the Concept': Reversibility Among the Siberian Yukaghirs. Journal of the Royal Anthropological Institute 13: 527-544.

Costa, Luiz, and Carlos Fausto. 2010. The Return of the Animists: Recent Studies of Amazonian Ontologies. Religion and Society: Advances in Research l (1): 89-109.

Course, Magnus. 2010. Of Words and Fog: Linguistic Relativity and Amerindian Ontology. Anthropological Theory 10 (3): 247-263.

Davis, Mike. 2006. Planet of Slums. London/Brooklyn: Verso.

de la Cadena, Marisol. 2010. Indigenous Cosmopolitics in the Andes: Conceptual Reflections Beyond 'Politics'. Cultural Anthropology 25 (2): 334-370. 
2014. The Politics of Modern Politics Meets Ethnographies of Excess through Ontological Openings. Theorizing the Contemporary. Cultural Anthropology Online. http://www.culanth.org/fieldsights/471-the-politicsof-modern-politics-meets-ethnographies-of-excess-through-ontologicalopenings. Accessed 19 Mar 2016.

. 2015. Earth Beings: Ecologies of Practice across Andean Worlds. Durham: Duke University Press.

Deonandan, Kalowatie, and Michael L. Dougherty, eds. 2016. Mining in Latin America: Critical Approaches to the New Extraction (Routledge Studies of the Extractive Industries and Sustainable Development). lst ed. London/New York: Routledge.

Descola, Philippe. 2014a. All too Human (still): A Comment on Eduardo Kohn's How Forests Think. HAU: Journal of Ethnographic Theory 4 (2): 267-273.

- 2014b. La Composition des Mondes: Entretiens avec Pierre Charbonnier. Paris: Flammarion.

- 2014c. Modes of Being and Forms of Predication. HAU: Journal of Ethnographic Theory 4 (1): 271-280.

- 2014d. The Difficult Art of Composing Worlds (and of Replying to Objections). HAU: Journal of Ethnographic Theory 4 (3): 431-443.

Descola, Philippe, and Tim Ingold. 2014. Etre au Monde. Quelle Expérience Commune? Lyon: Presses Universitaires de Lyon.

Erikson, Philippe. 1986. Altérité, tatouage et anthropophagie chez les Pano: la belliqueuse quête du soi. Journal de la Société des Américanistes 72: 185-210.

- 1999. El Sello de los Antepasados. Marcado del Cuerpo y Demarcación Etnica entre los Matis de la Amazonía. Quito: ABYA-YALA, IFEA.

Escobar, Arturo. 2016. Sentipensar con la Tierra: Las Luchas Territoriales y la Dimensión Ontológica de las Epistemologías del Sur. AIBR, Revista de Antropología Iberoamericana 11 (01): 11-32.

Fabricant, Nicole. 2013. Good Living for Whom? Bolivia's Climate Justice Movement and the Limitations of Indigenous Cosmovisions. Latin American and Caribbean Ethnic Studies, Special Issue: The Politics of Indigeneity in Bolivia 8 (2): 159-178.

Fausto, Carlos. 2012 [2001]. Warfare and Shamanism in Amazonia. Cambridge: Cambridge University Press.

Fischer, Michael. 2014. The Lightness of Existence and the Origami of 'French' Anthropology: Latour, Descola, Viveiros de Castro, Meillassoux, and Their So-Called Ontological Turn. HAU: Journal of Ethnographic Theory 4 (1): 331-355.

Fortis, Paolo. 2014. Artefacts and Bodies Among Kuna People from Panamá. In Making and Growing. Anthropological Studies of Organisms and Artefacts, ed. Elizabeth Hallam and Tim Ingold. Farnham: Ashgate Publishing. 
Franklin, Sarah. 2017. Situated Apprehensions: A Comment on Ashley Lebner's 'Interpreting Strathern's “Unconscious” Critique of Ontology'. Social Anthropology 25 (2): 228-229.

Fraser, Nancy. 2012. Feminism, Capitalism, and the Cunning of History: An Introduction. FMSH-WP-2012-17.

Friedman, Jonathan. 1999. Indigenous Struggles and the Discreet Charm of the Bourgeoisie. The Australian Journal of Anthropology 10 (1): 1-14.

Gago, Verónica. 2015. La razón neoliberal: Economías barrocas y pragmática popular. Buenos Aires: Tinta Limón.

García, María Elena. 2005. Making Indigenous Citizens: Identities, Education, and Multicultural Development in Peru. Palo Alto: Stanford University Press.

- 2008. Introduction: Indigenous Encounters in Contemporary Peru. Latin American and Caribbean Studies 3 (3): 217-226.

Goldstein, Daniel M. 2016. Owners of the Sidewalk: Security and Survival in the Informal City. Durham/London: Duke University Press.

Gordillo, Gastón. 2014. Rubble: The Afterlife of Destruction. Durham/London: Duke University Press.

Gudynas, Eduardo. 2011. Debates sobre el desarrollo y sus alternativas en América Latina: una breve guía heterodoxa. In Más allá del dessarrollo, ed. Grupo Permanente de Trabajo sobre Alternativas al Desarrollo. Quito: Abya Yala y Fundación Rosa Luxemburg.

- 2018. Extractivismos y corrupción en América del Sur. Estructuras, dinámicas y tendencias en una íntima relación. Revista de Ciencias Sociales y Humanas 10 (10): 73-87.

Gutiérrez, Manuel. 2001. La Perspectiva de los Súbditos Indios del Emperador. In De la Unión de Coronas al Imperio de Carlos V, ed. E. Belenguer. Madrid: Sociedad Estatal para la Conmemoración de los Centenarios de Felipe II y Carlos V, Volumen II.

Hage, Ghassan. 2012. Critical Anthropological Thought and the Radical Political Imaginary Today. Critique of Anthropology 32 (3): 285-308.

Halbmayer, Ernst. 2012. Debating Animism, Perspectivism and the Construction of Ontologies. Indiana 29: 9-23.

Haraway, Donna. 2008. When Species Meet. Minneapolis: University of Minnesota Press.

. 2016. Staying with the Trouble: Making Kin in the Chthulucene. Durham: Duke University Press.

Haraway, Donna, Noboru Ishikawa, Scott F. Gilbert, Kenneth Olwig, Anna L. Tsing, and Nils Bubandt. 2016. Anthropologists are Talking-About the Anthropocene. Ethnos 81 (3): 535-564.

Harris, Olivia. 2000. To Make the Earth Bear Fruit: Ethnographic Essays on Fertility, Work and Gender in Highland Bolivia. London: Institute of Latin American Studies. 
Harvey, David. 2007. Neoliberalism as Creative Destruction. The Annals of the American Academy of Political and Social Science 610 (1): 21-44.

Harvey, Penny, and Hannah Knox. 2015. Roads: An Anthropology of Infrastructure and Expertise. Ithaca: Cornell University Press.

Hasland, Paul A., and Pablo Heidrich, eds. 2016. The Political Economy of Natural Resources and Development: From Neoliberalism to Resource Nationalism (Routledge Studies in Development Economics, lst ed.). London/New York: Routledge.

HAU: Journal of Ethnographic Theory. n.d. HAU: Journal of Ethnographic Theory. https://www.haujournal.org/index.php/hau/index. Accessed 22 June 2017.

Henare, Amiria, Martin Holbraad, and Sari Wastell, eds. 2007. Thinking through Things: Theorising Artefacts Ethnographically. London: Routledge.

Heywood, Paolo. 2012. Anthropology and What There Is: Reflections on 'Ontology'. The Cambridge Journal of Anthropology 30 (1): 143-151.

High, Casey. 2015. Victims and Warriors: Violence, History, and Memory in Amazonia. Champaign: University of Illinois Press.

Holbraad, Martin. 2009. Ontology, Ethnography, Archaeology: An Afterword on the Ontography of Things. Cambridge Archaeological Journal 19 (3): 431-441.

- 2012. Truth in Motion: The Recursive Anthropology of Cuban Divination. Chicago/London: The University of Chicago Press.

- 2014. Tres Provocaciones Ontológicas. Ankulegi 18: 127-139.

Holbraad, Martin, and Morten Axel Pedersen. 2017. The Ontological Turn: An Anthropological Exposition. Cambridge: Cambridge University Press.

Hornborg, Alf. 2006. Knowledge of Persons, Knowledge of Things: Animism, Fetishism, and Objectivism as Strategies for Knowing (or not Knowing) the World. Ethnos 71 (1): 21-32.

Howe, Cymene. 2015. Latin America in the Anthropocene: Energy Transitions and Climate Change Mitigations. The Journal of Latin American and Caribbean Anthropology 20 (2): 231-241.

Ingold, Tim. 2000. The Perception of the Environment: Essays on Livelibood, Dwelling and Skill. London: Routledge.

- 2013. Making: Anthropology, Archaeology, Art and Architecture. London: Routledge.

Ingold, Tim, and Elizabeth Hallam. 2014. Making and Growing: An Introduction. In Making and Growing: Anthropological Studies of Organisms and Artefacts, ed. Elizabeth Hallam and Tim Ingold. Farnham: Ashgate Publishing.

Jalbert, Kirk, Anna Willow, David Casagrande, and Stephanie Paladino, eds. 2017. ExtrACTION: Impacts, Engagements, and Alternative Futures. London/New York: Routledge.

Kapfhammer, Wolfgang. 2012. Amazonian Pain: Indigenous Ontologies and Western Eco-Spirituality. Indiana 29: 145-169. 
Kawa, Nicholas. 2016. Amazonia in the Anthropocene. Austin: University of Texas Press.

Keane, Webb. 2013. Ontologies, Anthropologies and Ethical Life. Comment on Lloyd, G. E. R. 2012. Being, Humanity, and Understanding. Oxford: Oxford University Press. Hau: Journal of Ethnographic Theory 3(1): 186-191.

Kelly, John. 2014. The Ontological Turn: Where Are We? HAU: Journal of Ethnographic Theory 4 (1): 357-360.

Killick, Evan. 2014. Whose Truth Is It Anyway? A Review of Truth in Motion: The Recursive Anthropology of Cuban divination. Anthropology of this Century 9. http://aotcpress.com/articles/truth/. Accessed 19 Mar 2016.

- Perspectives on Climate Change and Its Mitigation: Ontological Wars in Amazonia. (Keynote Paper given at the Conference, Trans-Environmental Dynamics: Understanding and Debating Ontologies, Politics, and History in Latin America, LMU Munich October 2015.) https://www.academia. edu/20759277/Perspectives_on_Climate_Change_and_its_Mitigation_ Ontological_Wars_in_Amazonia. Accessed 29 Jan 2018.

Kohn, Eduardo. 2009. A Conversation with Philippe Descola. Tipiti: Journal of the Society for the Anthropology of Lowland South America 7 (2): 135-150.

- 2013. How Forests Think: Toward an Anthropology Beyond the Human. Oakland: University of California Press.

- 2015. Anthropology of Ontologies. Annual Review of Anthropology 44: $311-327$.

Latour, Bruno. 2005. Reassembling the Social: An Introduction to Actor-NetworkTheory. Oxford: Oxford University Press. $1-18$.

- 2014. Agency at the Time of the Anthropocene. New Literary History 45:

- 2015. Los Modernos, Según la Antropología. Ñ. Revista de Cultura (Clarin). http://www.revistaenie.clarin.com/ideas/Bruno-Latour-modernosantropologia_0_1295270475.html. Accessed 19 Mar 2016.

Law, John, and Marianne E. Lien. 2012. Denaturalising Nature. Public Inaugural Sawyer Seminar talk at University of California, Davis. https://www.sv.uio.no/ sai/english/research/projects/newcomers/publications/working-papersweb/denanturalisingnaturetalk2.pdf. Accessed 19 Jan 2018.

Lebner, Ashley. 2017. Interpreting Strathern's 'Unconscious' Critique of Ontology. Social Anthropology 25 (2): 221-233.

Lerner, Steve. 2010. Sacrifice Zones: The Front Lines of Toxic Chemical Exposure in the United States. Cambridge, MA: MIT Press.

Li, Fabiana. 2015. Unearthing Conflict: Corporate Mining, Activism, and Expertise in Peru. Durham: Duke University Press.

Matthes, Sebastian, and Zeljko Crncic. 2012. 'Extractivism.' InterAmerican Wiki: Terms - Concepts - Critical Perspectives. www.uni-bielefeld.de/cias/wiki/e Extractivism.html. Accessed 26 Jan 2018. 
McNeish, John-Andrew, Axel Borchgrevink, and Owen Logan, eds. 2015. Contested Powers: The Politics of Energy and Development in Latin America. London: Zed Books.

Merino, Roger. 2016. An Alternative to 'Alternative Development'?: Buen Vivir and Human Development in Andean Countries. Oxford Development Studies 44 (3): 271-286.

Mitchell, Timothy. 2011. Carbon Democracy. Political Power in the Age of Oil. London/Brooklyn: Verso.

Mol, Annemarie. 1999. Ontological Politics: A Word and Some Questions. The Sociological Review 47 (S1): 74-89.

Murray Li, Tanya. 2010. Indigeneity, Capitalism, and the Management of Dispossession. Current Anthropology 51 (3): 385-414.

Narotzky, Susana. 2010. Las antropologías hegemónicas y las antropologías del sur: el caso de España. Antípoda 11: 241-258.

Nash, June, ed. 1979. We Eat the Mines and the Mines Eat Us: Dependency and Exploitation in Bolivian Tin Mines. New York: Columbia University Press.

Neurath, Johannes. 2015. Shifting Ontologies in Huichol Ritual and Art. Anthropology and Humanism 40 (1): 58-71.

Nielsen, Axel. 2016. Home-Making Among South Andean Pastoralists. In The Archaeology of Andean Pastoralism, ed. José Capriles and Nicholas Tripcevich. Albuquerque: University of New Mexico Press.

Nixon, Rob. 2013. Slow Violence and the Environmentalism of the Poor. Cambridge, MA: Harvard University Press.

Ødegaard, Cecilie Vindal. 2010. Mobility, Markets and Indigenous Socialities: Contemporary Migration in the Peruvian Andes. Surrey: Ashgate Publishing.

- 2016. Alterity, Predation, and Questions of Representation: The Problem of the Kharisiri in the Andes. In Critical Anthropological Engagements in Human Alterity and Difference, ed. B.E. Bertelsen and S. Bendixsen. London: Palgrave Macmillan.

Orta, Andrew. 2004. Catechizing Culture. Missionaries, Aymara and the "New Evangelization". New York/Chichester: Columbia University Press.

Ortiz Rescaniere, Alejandro. 1999. El Individuo Andino, Autóctono y Cosmopolita. In Cultura y globalización, ed. Carlos Iván Degregori and Gonzalo Portocarrero. Lima: PUCP, Universidad del Pacífico, IEP.

Oyuela-Caycedo, A. 2014. Book review of Brightman, M., V. E. Grotti, and O. Ulturgasheva. 2012. Animism in Rainforest and Tundra: Personhood, Animals, Plants and Things in Contemporary Amazonia and Siberia. Bulletin of Latin American Research 33 (4): 536-537.

Pazos, Álvaro. 2006. Recensión Crítica de Philippe Descola Par-delà Nature et Culture. AIBR. Revista de Antropología Iberoamericana l (1): 186-194.

- 2007. Recensión Crítica de Tierra Adentro. Territorio Indígena y Percepción del Entorno. AIBR: Revista de Antropología Iberoamericana 2 (2): 369-377. 
Pazzarelli, Francisco. 2013. Otros-maices: trayectorias y transformaciones culinarias del maíz en Ambato (Catamarca, Noroeste Argentino). Revista Española de Antropología Americana 43 (2): 329-351.

Pedersen, Morten Axel. 2014. A Reader's Guide to the 'Ontological Turn'-Part 3. Somatosphere. http://somatosphere.net/2014/02/a-readers-guide-to-theontological-turn-part-3.html. Accessed 19 Mar 2016.

- 2017. Strathern and Ontology: An Awkward Relationship-A Comment on Lebner. Social Anthropology 25 (2): 229-230.

Piette, Albert. 2012. De l'Ontologie en Anthropologie. Paris: Berg International. Pitarch, Pedro. 2003. Infidelidades indígenas. Revista de Occidente 269: 60-76.

Platt, Tristan. 1982. The Role of the Andean Ayllu in the Reproduction of the Petty Commodity Regime in Northern Potosií (Bolivia). In Ecology and Exchange in the Andes, ed. David Lehmann. Cambridge: Cambridge University Press.

Portocarrero, Gonzalo. 1991. Sacaojos: crisis social y fantasmas coloniales. Lima: Tarea.

Postero, Nancy. 2013. Introduction: Negotiating Indigeneity. Latin American and Caribbean Ethnic Studies, Special Issue: The Politics of Indigeneity in Bolivia 8 (2): 107-121.

- 2017. The Indigenous State: Race, Politics, and Performance in Plurinational Bolivia. Oakland: University of California Press.

Povinelli, Elizabeth. 2001. Radical Worlds: The Anthropology of Incommensurability and Inconceivability. Annual Review of Anthropology 30: 319-334.

- 2012. Reclaiming Animism. E-flux 36. http://www.e-flux.com/journal/36/61245/reclaiming-animism/. Accessed 30 Jan 2018.

Ramos, Alcida Rita. 1998. Indigenism: Ethnic Politics in Brazil. Madison/London: University of Wisconsin Press.

- 2012. The Politics of Perspectivism. The Annual Review of Anthropology 41: 481-494.

Rata, Elizabeth. 1997. Global Capitalism and the Revival of Ethnic Traditionalism in New Zealand. PhD dissertation, University of Auckland.

Reed, Adam. 2016. Postscript: Taking the Ontological Turn Personally. In Critical Anthropological Engagements in Human Alterity and Difference, ed. B.E. Bertelsen and S. Bendixsen. London: Palgrave Macmillan.

Remme, Jon Henrik Ziegler. 2016. Chronically Unstable Ontology: Ontological Dynamics, Radical Alterity, and the 'Otherwise Within'. In Critical Anthropological Engagements in Human Alterity and Difference, ed. B.E. Bertelsen and S. Bendixsens. London: Palgrave Macmillan.

Rival, Laura. 2012a. Animism and the Meanings of Life: Reflections from Amazonia. In Animism in Rainforest and Tundra: Personhood, Animals, Plants and Things in Contemporary Amazonia and Siberia, ed. M. Brightman, V. Grotti, and O. Ulturgasheva. London: Berghahn Books. 
2012b. The Materiality of Life: Revisiting the Anthropology of Nature in Amazonia. Indiana 29: 127-143.

Rivera Andía, Juan Javier. 2005a. Killing What You Love: An Andean Cattle Branding Ritual and the Dilemmas of Modernity. Journal of Anthropological Research 61 (2): 129-156.

- 2005b. Territorio e identidad en los Andes. Concepciones populares en torno a las zonas ecológicas altas en la sierra de Lima. Revista de Dialectología $y$ Tradiciones Populares 40 (2): 55-76.

- 2006. Mitología en los Andes. In Mitologías Amerindias, ed. Alejandro Ortiz Rescaniere. Madrid: Trotta.

-2008. Apuntes sobre la alteridad constituyente en los Andes. Ambivalencias Rituales y Lingüísticas sobre un Espacio Imaginario. Revista Española de Antropología Americana 38 (1): 191-215.

- 2015. Amerindian Misfortunes: Ethnographies of South American Rituals and Cosmologies on Danger, Illness, and Evil. Indiana 32: 9-22.

Salmond, Amiria J.M. 2014. Transforming Translations (Part 2): Addressing Ontological Alterity. HAU: Journal of Ethnographic Theory 4 (1): 155-187.

Santos-Granero, Fernando. 2009. Introduction: Amerindian Constructional Views of the World. In The Occult Life of Things. Native Amazonian Theories of Materiality and Personhood, ed. Fernando Santos-Granero. Tucson: University of Arizona Press.

Schavelzon, Salvador. 2016. La política indígena y la investigación en Bolivia. Revista de Antropologia 59 (3): 115-149.

Scott, Michael W. 2013. The Anthropology of Ontology (Religious Science?). Journal of the Royal Anthropological Institute (N.S.) 19 (4): 859-872.

Shellenberger, Michael, and Ted Nordhaus. 2011. The Long Death of Environmentalism. The Breakthrough. http://thebreakthrough.org/archive/ the_long_death_of_environmenta. Accessed 27 Jan 2018.

Stengers, Isabelle. 1996. Cosmopolitiques: T1. La guerre des sciences. Paris: La Découverte.

- 2005. The Cosmopolitical Proposal. In Making Things Public: Atmospheres of Democracy, ed. Bruno Latour and Peter Weibel. Cambridge, MA: MIT Press.

- 2012. Reclaiming Animism. E-flux 36. http://www.e-flux.com/ journal/36/61245/reclaiming-animism/. Accessed 18 Jan 2018.

Steur, Luisa. 2014. Indigeneity and Precariousness: Ontological Criticism or Dialectical Force? FocaalBlog, July 17. www.focaalblog.com/2014/07/17/ indigeneity-and-precariousness-ontological-criticism-or-dialectical-force-byluisasteur. Accessed 9 Sept 2017.

Strathern, Marilyn. 2004. Partial Connections. New York: AltaMira.

Svampa, Maristella. 2013. 'Consenso de los Commodities' y lenguajes de valoración en América Latina. Nueva Sociedad 244: 30-46. 
Todd, Zoe. 2016. An Indigenous Feminist's Take on the Ontological Turn: 'Ontology' is Just Another Word for Colonialism. Journal of Historical Sociology 29 (1): 4-22.

Tsing, Anna Lowenhaupt. 2015. The Mushroom at the End of the World. Princeton: Princeton University Press.

Turner, Terry S. 2009. The Crisis of Late Structuralism: Perspectivism and Animism: Rethinking Culture, Nature, Spirit, and Bodiliness. Tipiti: Journal of the Society for the Anthropology of Lowland South America 7 (1): 3-40.

Tylor, E. 1871. Primitive Culture: Researches into the Development of Mythology, Philosophy, Religion, Art, and Custom. London: J. Murray.

Veltmeyer, Henry, and James Petras, eds. 2014. The New Extractivism: A PostNeoliberal Development Model or Imperialism of the Twenty-First Century? London: Zed Books.

Vigh, Henrik Erdman, and David Brehm Sausdal. 2014. From Essence Back to Existence: Anthropology Beyond the Ontological Turn. Anthropological Theory 14 (1): 49-73.

Viveiros de Castro, Eduardo. 1992. From the Enemy's Point of View: Humanity and Divinity in an Amazonian Society. Chicago: University of Chicago Press.

- 1998. Cosmological Deixis and Amerindian Perspectivism. The Journal of the Royal Anthropological Institute 4 (3): 469-488.

- 1999. Comments to "Animism Revisited: Personhood, Environment, and Relational Epistemology”. Current Anthropology 40: 79-80.

- 2004a. Exchanging Perspectives: The Transformation of Objects into Subjects in Amerindian Ontologies. Common Knowledge 10 (3): 463-484.

- 2004b. Perspectival Anthropology and the Method of Controlled Equivocation. Tipiti: Journal of the Society for the Anthropology of Lowland South America 2 (1): 3-22.

- 2011. The Inconstancy of the Indian Soul: The Encounter of Catholics and Cannibals in 16th Century Brazil. Chicago: Prickly Paradigm Press.

- 2015a. The Relative Native: Essays on Indigenous Conceptual Worlds. Chicago: Hau Books.

- 2015b. Who Is Afraid of the Ontological Wolf? Some Comments on an Ongoing Anthropological Debate. The Cambridge Journal of Anthropology 33 (1): 2-17.

Wade, Peter. 2017. Degrees of Mixture, Degrees of Freedom: Genomics, Multiculturalism, and Race in Latin America. Durham: Duke University Press.

Wardle, Huon, and Justin Shaffner, eds. 2017. Cosmopolitics: Collected Papers of the Open Anthropology Cooperative. Vol. I. St Andrews: Open Anthropology Cooperative Press.

Warren, Kay B., and Jean E. Jackson. 2002. Indigenous Movements, SelfRepresentation, and the State in Latin America. Austin: University of Texas Press. 
Willerslev, Rane. 2007. Soul Hunters: Hunting, Animism, and Personhood among the Siberian Yukaghirs. Berkeley: University of California Press.

2013. Taking Animism Seriously, but Perhaps Not Too Seriously? Religion and Society: Advances in Research 4 (1): 41-57.

Wolf, Eric. 1957. Closed Corporate Peasant Communities in Mesoamerica and Central Java. Southwestern Journal of Anthropology 13 (1): 1-18.

Open Access This chapter is licensed under the terms of the Creative Commons Attribution 4.0 International License (http://creativecommons.org/licenses/ by $/ 4.0 /)$, which permits use, sharing, adaptation, distribution and reproduction in any medium or format, as long as you give appropriate credit to the original author(s) and the source, provide a link to the Creative Commons license and indicate if changes were made.

The images or other third party material in this chapter are included in the chapter's Creative Commons license, unless indicated otherwise in a credit line to the material. If material is not included in the chapter's Creative Commons license and your intended use is not permitted by statutory regulation or exceeds the permitted use, you will need to obtain permission directly from the copyright holder.

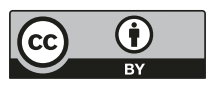

